\title{
TAX BASE VARIABILITY AND PROCYCLICAL FISCAL POLICY
}

\author{
Ernesto Talvi \\ Carlos A. Végh \\ Working Paper 7499 \\ http:/www.nber.org/papers/w7499
NATIONAL BUREAU OF ECONOMIC RESEARCH 1050 Massachusetts Avenue
Cambridge, MA 02138
January 2000

\begin{abstract}
An earlier version of this paper, which circulated under the title, "Can Optimal Fiscal Policy Be Procyclical?," was written while Talvi was a Senior Economist and Végh a Visiting Scholar at the Office of the Chief Economist, Inter-American Development Bank (IADB). We are grateful to Joshua Aizenman, Phil Lane, Andy Neumeyer, Torsten Persson, Ratna Sahay, Mariano Tommasi, and seminar participants at the Board of Governors, CEMA (Buenos Aires), IMF, PUC (Rio de Janeiro), UC Irvine, UCLA, the University of Washington, the Universidad de La Plata (Argentina), Universidad Di Tella (Buenos Aires), the World Bank, LACEA (Chile), and the 1999 Winter Camp in Cartagena for helpful comments and suggestions. We thank Ricardo Adrogue, Alejandro Grisanti, and Alessandro Rebucci for excellent research assistance. The views expressed herein are those of the authors and not necessarily those of the National Bureau of Economic Research or the IADB..
\end{abstract}

- 2000 by Emesto Talvi and Carlos A. Végh. All rights reserved. Short sections of text, not to exceed two paragraphs, may be quoted without explicit permission provided that full credit, including $@$ notice, is given to the source. 
Tax Base Variability and Procyclical Fiscal Policy

Ernesto Talvi and Carlos A. Végh

NBER Working Paper No. 7499

January 2000

JEL No. F41, H30

\begin{abstract}
Based on a sample of 56 countries, we find that while fiscal policy in the G-7 countries appears to be broadly consistent with Barro's tax smoothing proposition, in developing countries government spending and taxes are highly procyclical (i.e., government spending rises and taxes fall during expansions, while the reverse is true in recessions). To explain this puzzle, we develop an optimal fiscal policy model in which running budget surpluses is costly because they create pressures to increase public spending. Given this distortion, a government that faces large (and perfectly anticipated) fluctuations in the tax base will find it optimal to run a procyclical fiscal policy. We argue that the differences in fiscal policy between the G-7 countries and developing countries can be traced back to the fact that the tax base is much more volatile in developing countries than in the G-7 countries.
\end{abstract}

Ernesto Talvi

CERES

Antonio Costa 3476

Montevideo, Uruguay

etalvi@ceres-uy.org
Carlos A. Végh

Department of Economics

UCLA

Los Angeles, CA 90095

and NBER

cvegh@ucla.edu 


\section{Introduction}

How should fiscal policy be set over the business cycle? This question has intrigued several generations of economists. Standard Keynesian models imply that fiscal policy should be countercyclical: when bad times hit, the government should increase government spending and lower taxes to help the economy "spend" its way out of the recession. At the other extreme, tax-smoothing models inspired in Barro (1979) imply that fiscal policy should remain essentially neutral over the business cycle (and respond only to unanticipated changes that affect the government's budget constraint). Hence, if policymakers followed Keynesian prescriptions, one should observe over the business cycle a positive correlation between tax rates and output and a negative correlation between government spending and output. In contrast, if policymakers followed Barro's prescriptions, those correlations should be essentially zero. ${ }^{1}$

What does the evidence show? For G-7 countries, the correlation between government consumption and output indeed appears to show no pattern and be clustered around zero (see, for example, Fiorito and Kollintzas (1994) and Fiorito (1997)). Due to the inherent difficulties in computing tax rates, correlations between tax rates and output are harder to come by. For the United States, however, Barro (1990), Huang and Lin (1993), and Strazicich (1997) conclude that federal tax rates are set so as to smooth out predictable changes in government spending. The inflation tax rate, in turn, appears to increase during expansions and decline during recessions (see Cooley and Hansen (1995)).

In sharp contrast to the evidence for industrial countries, recent work by Gavin et al (1996) and Gavin and Perotti (1997a) suggests that fiscal policy in Latin America is procyclical. ${ }^{2}$ During expansions, government consumption increases and taxes fall, while the opposite is true during recessions. Furthermore, the inflation tax is also low in expansions and high in recessions. Fiscal policy in Latin America thus appears to differ substantially relative to OECD countries and not to conform with either Keynesian or Barro prescriptions. ${ }^{3}$

In light of this puzzling behavior, a natural question to ask is whether this is exclusively a Latin American phenomenon or rather a more widespread phenomenon related to some fundamental characteristic of fiscal policy in developing countries. The evidence provided in this paper (Section 2) clearly suggests that procyclical fiscal policy is so pervasive in the world economy that it should arguably be viewed as the rule rather than the exception. Indeed, for a sample of 56 countries (20 industrial and

\footnotetext{
${ }^{1}$ Although not tipically modeled, it would be clearly in the spirit of Barro (1979) to keep government consumption constant in response to, say, shocks to the tax base. (As formally shown below, a model in which government consumption yields utility delivers such a result.) Note also that Barro's tax-smoothing prescription applies to the inflation tax rate, which should remain constant in response to anticipated shifts in goverment expenditures; see Calvo and Guidotti (1993).

${ }^{2}$ Throughout this paper, a procyclical fiscal policy with respect to taxes is defined as increases in tax rates during recessions and reductions in tax rates during expansions. This definition stresses the notion that movements in tax rates tend to reinforce the business cycle. In the same vein, procyclical government consumption will be defined as government consumption increasing in good times and decreasing in bad times.

${ }^{3}$ Further evidence on OECD countries is provided by Hercovitz and Strawczynski (1998). See Lane (1998) on fiscal policy in Ireland.
} 
36 developing countries), we find that, in line with previous studies, the correlation between the cyclical components of government consumption and output in the G-7 countries is close to zero. However, this is not the case in the rest of our sample. For starters, as a group, non-G-7 industrial countries are procyclical, with 9 out of the 14 countries having a positive correlation between government consumption and output. Developing countries as a group are even more procyclical and, quite remarkably, the correlation is positive in every single one of the 36 developing countries in our sample. When it comes to the inflation tax, our findings confirm that in industrial countries inflation increases during expansions and falls during recessions and that the opposite is true for the developing world as a whole. The evidence thus suggests that procyclicality of fiscal policy is a puzzle in search of an explanation. ${ }^{4}$

Our explanation for the puzzling behavior of fiscal policy in developing countries starts from the observation that fluctuations in the tax base are much larger in developing countries than in the G-7 countries. Under these circumstances, full tax smoothing would imply running large budget surpluses in good times and large budget deficits in bad times. However, the ability to run large budget surpluses in good times is severely hampered by political pressures which - although always present - get exacerbated in times of plenty. As a result, fiscal resources may be wasted in favor of, among others, government agencies, state-owned enterprises, provinces or states, and rent-seekers rather than being used to retire debt, as full tax smoothing would require. ${ }^{5}$ In fact, it is not unusual for finance ministers in Latin America to argue that the potential for misusing resources in good times makes it preferable to avoid large surpluses by lowering taxes, thus allowing the private sector to use those resources as it sees fit. ${ }^{6}$ Deviations from a full tax smoothing rule may thus be an indirect way of resisting spending pressures.

We formalize this idea by incorporating into an otherwise standard optimal fiscal policy model (a la Lucas and Stokey (1983)) a political distortion which makes it costly to run budget surpluses due to the pressures they create to increase public spending. ${ }^{7} \quad$ Given this political distortion, a government that faces large (and

\footnotetext{
${ }^{4}$ Unfortunately, there is no readily available data on conventional tax rates. Casual empiricism, however, strongly suggests that tax rates are indeed procyclical in developing countries. The cases of Argentina and Mexico during 1995 provide a striking illustration. In the midst of a severe recession, both countries implemented major fiscal adjustments involving large increases in tax rates (together, of course, with substantial cuts in public spending). In the case of Mexico, the value-added tax rate was increased from 10 to 15 percent. On the other hand, during the economic boom in Argentina in 1991-94, tax rates were reduced with the explicit purpose of avoiding large surpluses (further details are provided in Section 3).

${ }^{5}$ As analyzed in detail in Section 3 , commodity booms offer a laboratory-type experiment to analyze the spending pressures that arise when government's coffers are quickly filled.

${ }^{6}$ This view was repeatedly stated by Domingo Cavallo who, as finance minister of Argentina during 1991-1996, presided over a far-reaching and successful stabilization and reform program.

${ }^{7}$ It should be noted that our main purpose is not to model this political distortion, but rather to take it as given and analyze its public finance implications. The political distortion itself may be viewed as a reduced form arising from a political economy model. One possible rationalization is given by Tornell and Lane (1999), who show that, as a result of a common pool problem, a positive terms of trade shock may lead to a more than proportional change in fiscal appropriations. (See also Tornell and Lane (1998) and Lane and Tornell (1998)). A related mechanism is emphasized by Velasco (1993) in the context of a model in which interest groups can sucessfully lobby the fiscal
} 
perfectly anticipated) fluctuations in the tax base will choose to lower taxes in good times to fend off spending pressures. However, since reducing taxes in good times imposes intertemporal distortions, it will not be optimal for the government to resist all increases in public spending. Hence, an optimal policy response to positive shocks in the tax base will involve both decreasing tax rates and raising spending. The opposite is true when the economy is hit by negative shocks to the tax base. In other words, our model predicts that, given this political distortion, optimal fiscal policy is procyclical. $^{8}$

How de we interpret, in light of our model, the differences in fiscal policy between G-7 countries, non-G-7 industrial countries, and developing countries? We argue that these differences reflect the fact that the tax base fluctuates the most in developing countries and the least in the G-7 countries, with non-G-7 industrial countries falling somewhere in the middle. In fact, as documented below, the variability of the tax base (i.e., output or consumption) in developing countries is between two and four times higher than in G-7 countries. In terms of the model, if fluctuations in the tax base are small, spending pressures will not play much of a role and full tax smoothing will hold as an approximation. In contrast, when fluctuations in the tax base (and hence in the budget surplus) are large, political pressures become harder to resist and will have a major impact on fiscal policy. This implies that the larger the variability of the tax base, the more procyclical fiscal policy will be.

Two additional implications of the model are worth stressing. First, the procyclical response of fiscal policy leads to fluctuations in consumption and output. Policy-induced volatility thus reinforces the volatility of the underlying economic environment. In this context, it would be incorrect to blame policymakers for unstable macroeconomic policies. Our model suggests that the root of unstable policies may lie, not in policymakers' inability to set the "correct" policies, but rather in the political economy of fiscal arrangements. Second, during recessions, it might appear as though the economy is not borrowing enough, which may be construed as evidence of lack of access to international credit markets (i.e., credit rationing). In the model, however, it is the inability of the government to generate large enough surpluses during expansions that forces it to borrow less during recessions - relative to a full-tax smoothing rule - in order to satisfy its solvency constraint.

Our explanation contrasts with the received wisdom on this issue (see Aizenman, Gavin, and Hausmann (1996) and Gavin and Perotti (1997a, 1997b)), which holds that procyclical fiscal policy is mainly explained by the fact that countries are cut off from international credit markets in bad times. ${ }^{9}$ This explanation, however, is not without problems. At a theoretical level, if the government knows that it will

authority and thus induce inefficiently high levels of government spending. (See Alesina and Perotti (1994) for a review of the political economy of budget deficits in relation to OECD countries.)

${ }^{8}$ For the sake of brevity, we only present a real model of optimal taxation. However, by introducing money in the utility function, it is easy to check that the optimal inflation tax would also be procyclical (for the same intuitive reasons).

${ }^{9}$ Persson (1997) advocates a third explanation based on the effects of realized inflation on real government expenditures. This could explain why budget surpluses are particularly high during recessions, which are also periods of high inflation. Persson, Persson, and Svensson (1996) argue that this channel is particularly important in the case of Sweden. 
lose access to international credit markets during bad times, it is not clear that it will let the borrowing constraint bind. At an empirical level, although it would be hard to disagree with the notion that some countries on some occasions have faced international credit rationing, it would seem somewhat farfetched to argue that every developing country - and even several industrial countries - have lost access to international credit markets during recessions on a systematic basis over the last 25 years. In fact, as our evidence in Section 2 suggests and Lane (1999) shows with much more refined econometric work, procyclicality of fiscal policy is also present in many OECD countries for which lack of access to international credit markets has not been typically an issue.

Sorting out the empirical relevance of these contrasting explanations for procyclical fiscal policy could have important implications from a public policy perspective. While the credit rationing explanation would focus on the need to ensure - through various financial mechanisms - that countries have access to liquidity in bad times, our explanation suggests that emphasis ought to be placed in reforming domestic fiscal institutions to ensure that fiscal surpluses are saved in good times. In this sense, therefore, our analysis reinforces the public policy implications of the work by Lane and Tornell (1998) and Tornell and Lane (1998, 1999), which also points to the importance of implementing the appropriate fiscal allocations mechanisms.

The paper proceeds as follows. Section 2 documents the business cycle properties of fiscal variables for a large sample of industrial and developing countries. Section 3 illustrates the outbreak of political pressures to spend in good times during episodes in which fiscal revenues increase dramatically (i.e., commodity booms). Section 4 presents a real model of optimal taxation with consumption taxes, which incorporates a political distortion. Section 5 shows the conditions under which, in the absence of the political distortion, full tax smoothing is optimal. We use this case as our benchmark. Section 6 contains the main results of the paper: we show that exogenous shocks to non-tax revenues and to the tax base lead to an optimal procyclical fiscal policy. Section 7 shows that analogous results obtain for labor income taxation. Section 8 interprets the evidence described in Section 2 in terms of the model. Finally, Section 9 concludes.

\section{Business cycle properties of fiscal policy}

How is fiscal policy conducted over the business cycle? To answer this question, this section reviews the most salient features of the business cycle properties of fiscal variables for a group of 56 countries, which comprises 20 industrial countries and 36 developing countries. These properties refer to moments of Hodrick-Prescott filtered variables. We focus on volatility, as measured by the standard deviation, and comovement, as measured by correlations, for a set of common macro and fiscal variables to compare the experience of developing countries with that of industrial countries. We use annual data from the IMF's International Finance Statistics and Government Finance Statistics and the Inter-American Development Bank (IADB). ${ }^{10}$

\footnotetext{
${ }^{10}$ The choice of annual frequency is due to the lack of quarterly data for several variables in developing countries.
} 
Table 1 indicates that, on average, output is twice as volatile in developing countries as in the industrial countries, while private consumption is about three times as volatile. ${ }^{11}$ Furthermore, consumption is 70 percent more volatile than output in developing countries. Such variability in consumption is important because tax systems in developing countries are often based on consumption taxes, rather than on income taxes as in industrial countries. The evidence thus suggests that tax bases are considerably more volatile in developing countries than in industrial countries. As will become clear below, this higher variability will play an important role in our model's predictions.

Table 1 also presents evidence on the comovement between (the cyclical components of) output and the most relevant fiscal variables. The main findings are as follows. First, fiscal revenues are procyclical (i.e., the correlation between output and revenues is positive) in both developing and industrial countries. In both cases, the correlation coefficient is statistically different from zero at the one percent level. Of course, this comes as no surprise since any standard optimal tax-smoothing model would imply procyclical tax revenues (as opposed to tax rates) in response to shocks to the tax base.

Second, the only group in which government consumption is not correlated with output over the cycle is the G-7 countries. In every other group, this correlation is positive and statistically different from zero. In the non-G7 industrial countries, government consumption is procyclical, with the correlation coefficient being 0.25 . In developing countries, government consumption is highly procyclical (the correlation coefficient is 0.53 ), reflecting a positive correlation in every single one of the 36 developing countries in our sample (see Table A.1 in the appendix).

To test whether average correlations between government consumption and output differ within and across regions, we perform a series of F-tests. First, the hypothesis that average correlations across developing country regions are the same cannot be rejected, suggesting that the procyclicality of government consumption is a pervasive phenomenon in the developing world. Second, the hypothesis that average correlations for developing countries and industrial countries are equal is rejected at the one percent level. Even the behavior within the industrialized world is not homogenous. In fact, the hypothesis that average correlations for G-7 and non-G7 industrial countries are equal is rejected at the 10 percent level. In sum, these results clearly indicate that the procyclical behavior of government consumption is a widespread phenomenon - which is certainly not confined to Latin America as documented in Gavin et al (1996) and Gavin and Perotti (1997a). This is the first puzzle in search of an explanation.

Third, the inflation tax rate is countercyclical in industrial countries (i.e., the inflation tax increases during expansions and falls during recessions). ${ }^{12}$ The correlation coefficient between the inflation tax and output is positive (0.23) and significantly different from zero at the one percent level. The opposite is true for developing coun-

\footnotetext{
${ }^{11}$ The difference in the average volatilities is significant at the 1 percent level for output and 5 percent for consumption.

${ }^{12}$ The inflation tax rate is defined as $\frac{\pi}{1+\pi}$, where $\pi$ is the inflation rate. Hence, the inflation tax rate is bounded between zero and one.
} 
tries. The correlation coefficient between the inflation tax and output for developing countries is negative (-0.09) and significantly different from zero at the 10 percent level. In fact, F-tests (not reported) indicate that the hypothesis that the average correlations for industrial and developing countries are the same is rejected at the one percent level. This procyclical behavior of tax rates constitutes the second puzzle in search for an explanation. ${ }^{13}$

In sum, the cyclical behavior of fiscal policy in developing countries (in terms of government consumption and tax rates), and even in some industrial countries, is puzzling both in terms of the existing body of theory and when compared to the G-7 countries. This evidence raises the question of whether one can construct a neoclassical optimal fiscal policy model which delivers procyclical fiscal behavior as an optimal response to exogenous shocks. The model developed in Section 4 yields such an optimal fiscal policy as a result of the interaction between a variable tax base and political distortions. Before proceeding to the model, and as a way to motivate the role of political factors, the next section analyzes evidence from commodity booms episodes which suggests that revenue booms give rise to political pressures for additional spending.

\section{Revenue booms, government spending, and politics}

Political pressures for additional spending in good times will play a critical role in the setup of our model. From a formal point of view, the model will take as given such political pressures since the focus is on explaining deviations by a benevolent fiscal authority from Barro-type tax-smoothing policies. This section motivates our emphasis on political factors by first discussing the reaction of government spending to extraordinary increases in revenues due to rises in commodity prices. The magnitude of the resulting windfall gains is such that these episodes constitute almost laboratorytype experiments for the analysis of the emergence of spending pressures when fiscal resources are abundant. It then discusses the role of political factors in accounting for these spending pressures.

Revenue booms and government spending A first experiment is provided by the oil shock of 1974. As illustrated in Table 2 - which is based on Gelb (1989) the average windfall gain during 1974-1978 was 21.7 percent of GDP. ${ }^{14}$ Notice first that, on average, only 17.9 percent of the windfall gain was saved. This implies, of course, that 82.1 percent of the windfall was spent. Remarkably, most of these resources were spent by the government ( 75.9 percent of the windfall gain) and only 6.2 percent by the private sector, as Table 2 indicates. Since, on average, around four fifths of the windfall gain accrued to the government, the private sector saved 70

\footnotetext{
${ }^{13}$ Again, we take the behavior of the inflation tax rate as also capturing the behavior of other, conventional, taxes. (Data on tax rates is extremely difficult to come by on any consistent basis.) Indeed, abundant casual evidence suggests that governments in developing countries increase tax rates in bad times.

${ }^{14}$ The windfall gain is computed as the value effect (i.e., price times oil sales) of the change in oil prices.
} 
percent of the windfall income gain, while the public sector saved only 5 percent of its windfall revenue gain. Put differently, the very low propensity to save out of what turned out to be a temporary shock was due mainly to the public sector's spending spree. A closer look at the fiscal accounts (Table 3) reveals that the government's marginal propensity to spend out of the windfall increase in revenues is high in every single country, ranging from 0.77 in Venezuela to 0.99 in Nigeria. ${ }^{15}$

As indicated in Table 2, a large fraction of the increase in government expenditures takes the form of public investment. In practice, however, most of the increase in public investment, although officially recorded as such, is actually government consumption. In a report titled "Ungenerous Endowments," The Economist (1995) describes the use of proceeds from commodity booms as follows:

All too often the proceeds of recent commodity windfalls have accrued to governments, either through taxes or because they nationalised the companies involved. Naturally enough, the governments then instituted lavish spending programmes ... Public spending is not always bad; indeed the right kind of public investment can be an important engine of economic growth. Inevitably, however, many of the public spending programmes put in place by countries enjoying a resource boom have not been of this kind. Economists who have sought to measure the effectiveness of such spending, for instance after the 1973 oil shock, have found that it often yielded minimal, zero or, in a few cases, even negative rates of return.

Given the low return of public investment associated with commodity booms, most of it should be viewed as falling essentially into the same category as government consumption since non-productive investment will not generate future consumption. ${ }^{16}$ While it is inherently difficult to establish how large is the proportion of non-productive investment during these commodity booms, estimates from Nigeria put it as high as 75 percent (The Economist (1995)). In this light, the increase in non-productive government expenditures resulting from a revenue bonanza is simply staggering.

A similar pattern of booming government revenues and expenditures was observed during the coffee boom of 1976-1978. Due to a severe frost in Brazil, the average price of coffee in 1977 was three times as high as the 1975 average. Furthermore, given the cause of the price increase, it was evident to all players involved that the price boom would be temporary. Little et al (1993) studied the effects of this coffee boom in five developing countries: Cameroon, Colombia, Costa Rica, Cote d'Ivoire, and Kenya. The extent to which the windfalls gains accrued to producers or the government varied greatly across countries. For example, in Costa Rica and Kenya, where the whole price rise accrued to producers, the rise in fiscal revenues came about through other channels, such as export taxes. In spite of these differences,

\footnotetext{
${ }^{15}$ Not taking into account the case of Ecuador, where revenues actually fell.

${ }^{16}$ At a more general level, Isham and Kaufmann (1998) calculate economic rates of return from a set of 1,276 public and private investment projects under monitoring by the World Bank. They find that when public investment exceeds 10 percent of GDP, it has an adverse effect on the return of individuals projects.
} 
"government revenues in four of the five countries doubled from 1975 to 1978 [and] [i]t did not take long for government expenditures to catch up with, and overtake, revenue ( Little et al (1993), pp. 40-41). As in the case of the oil boom, most of the increase in government expenditures showed up as investment. For instance, in Cote d'Ivoire the "government reacted to the coffee and cocoa boom of the mid-1970s by increasing its capital expenditures from 8 percent of GDP in 1975 to 22 percent in 1977. Private investment remained relatively stable during that period, at about 13 to 15 percent of GDP" (Chamley and Ghanen (1994, pp. 305)).

Political factors The evidence presented so far - which suggests that governments embark on a spending spree when faced with a windfall gain in revenues - is clearly at odds with standard optimal fiscal policy prescriptions. It is hard to think of economic reasons that should lead a government to increase its consumption so dramatically, as opposed to saving most of the windfall for a rainy day. Furthermore, such government behavior is in stark contrast to that of the private sector, which appears to save the bulk of these large windfalls as standard intertemporal models would predict.

In our view, this puzzling behavior can be traced back to the size of the fluctuations in fiscal revenues. Given such large fluctuations in fiscal revenues, smoothing both tax rates and government consumption a la Barro would imply running extremely large budget surpluses in good times. In practice, however, the ability to run such large budget surpluses during good times appears to be severely hampered by political pressures. While always present, these political pressures are particularly evident during times of plenty. In the words of The Economist (1995),

The trouble is that the lure of those fat rents can be hard to resist. The upshot is routinely an outbreak of competitive rent-seeking. The power centres in any resource-rich country soon notice that the profits from capturing a slice of the rent from natural resources beat those of any possible alternatives; and they act accordingly. Behind the economic jargon is a simple enough proposition: give a group of people a big pot of money and they will spend their time arguing how to share it out ... Experience bears this out. In Mexico in the 1970s, politicians and firms battled over the state's oil revenues. So it was in Venezuela, Nigeria, and several other big oil exporting countries. Nor is the experience restricted to oil exporters. Other resource-rich countries have blown the proceeds of their wealth in competitive rent-seeking: Australia and Brazil are outstanding examples.

In the same vein, Little et al (1993), based on a detailed study of 18 developing countries from 1974 to 1989 , conclude that economic booms leading to large increases in government revenues typically weaken treasury control" and that "[m]ost governments, democratic and authoritarian alike, are preoccupied with the short-run and find it hard to resist spending a windfall in revenues" (p. 378-9). Examples of spending binges and loss of fiscal control in the aftermath of positive terms of trade shocks include Indonesia after the first oil shock, Mexico and Nigeria after the second-oil shock, and Kenya during the coffee boom of the mid-1970's. They argue that "when funds are readily available, and known by all to be available, it requires exceptionally 
strong traditions and strong-willed financial officials backed by their political leaders to maintain fiscal discipline ..." (p. 379).

Although commodity booms in developing countries offer a unique opportunity to look at the outbreak of political pressures in times of plenty through a magnifying glass, such pressures are certainly not limited to periods of commodity booms. For instance, after the launching of a successful stabilization plan in 1991, Argentina went through a rapid economic expansion during 1991-1994. The resulting increase in tax revenues led to a substantial increase in government spending. At the same time, there was an active policy of reducing labor tax rates to prevent the fiscal surplus from rising too much. The rationale - as stated publicly, time and again, by the Minister of Finance, Domingo Cavallo - was that if the fiscal surplus were allowed to rise, political pressures would eat it away. Hence - the argument went - the surplus would be put to better use if it were handed back to the private sector through lower tax rates. ${ }^{17}$

Finally, some indirect evidence in favor of the notion that the abundance of resources stimulates spending pressures is given by the widespread practice on the part of finance ministers to purposely underestimate fiscal revenues in order to avert spending pressures. In fact, econometric evidence for 12 Latin American countries suggests that in volatile economies the treasury systematically underestimates fiscal revenues in order to prevent overspending (see Aizenman and Hausmann (1995)). The underlying logic is that spending agencies react asymmetrically when their allocated funds differ from realized expenditures. When there is a shortfall of funds, these agencies will always request additional funds from the treasury. In contrast, when there is an excess of funds these agencies will typically spend the extra funds. This asymmetry introduces an overspending bias, which the treasury attempts to curb by reducing the estimated revenues and, accordingly, the initial budget allocations.

In summary, three key stylized facts emerge from this section. First, the fluctuations in government revenues observed in economies which depend on volatile sources of revenue may be extremely large. Second, large temporary rises in government revenue result in correspondingly large increases in government consumption (i.e., actual government consumption plus non-productive public investment). Third, political factors - in particular the emergence of political pressures for additional spending during revenue bonanzas - appear to be of central importance in understanding the apparent inability of governments to save in good times. These stylized facts, together with the evidence presented in Section 2, suggest that high variability of fiscal revenues combined with increased spending pressures in good times may be key in explaining the procyclical nature of fiscal policy. These ideas are formalized in next section's model.

\footnotetext{
${ }^{17}$ In a recent interverview (Ambito Financiero, January 5, 1999), Cavallo argues against raising taxes to reduce the current fiscal deficit because" $[w]$ hen the federal government and the provinces get ... more revenues, they stop worrying about containing public spending ... It makes more sense to generate some fiscal deficit but reduce taxes, as we did, for example, [in 1994 and 1996] [b]ecause ... it puts pressure on those who manage public spending to prevent it from getting out of control ..." (Authors' translation.)
} 


\section{The model}

This section develops a simple perfect-foresight real model of optimal fiscal policy, which will be used in later sections to illustrate our main points. ${ }^{18}$ The analysis will first focus on the case of consumption taxes and then show that all results go through for the case of labor income taxation.

\subsection{The household's problem}

Consider a small open economy inhabited by a large number of identical, infinitelylived consumers, who are blessed with perfect foresight. The economy is perfectly integrated with the rest of the world in both goods and capital markets. The (constant) world real interest rate is denoted by $r$. There exists only one (tradable and non-storable) consumption good in the world.

Production of the only good in period $t, y_{t}$, takes place through a linear technology,

$$
y_{t}=\alpha_{t} \ell_{t}
$$

where $\ell_{t}$ denotes labor supplied in period $t$ and $\alpha_{t}$ is a productivity shock.

Let $f_{t}$ denote net foreign assets held by the representative consumer at the end of period $t$. The consumer's flow budget constraint is thus:

$$
f_{t}=(1+r) f_{t-1}+y_{t}-\left(1+\theta_{t}\right) c_{t}
$$

where $c_{t}$ is consumption in period $t$ and $\theta_{t}$ is the consumption tax. Assuming away Ponzi games, the flow constraint (4.2) implies that the household's lifetime expenditure is constrained only by its initial assets and the present discounted value of the output path:

$$
(1+r) f_{-1}+\sum_{t=0}^{\infty}\left(\frac{1}{1+r}\right)^{t} \alpha_{t} \ell_{t}=\sum_{t=0}^{\infty}\left(\frac{1}{1+r}\right)^{t} c_{t}\left(1+\theta_{t}\right)
$$

The representative household's lifetime utility is given by

$$
\sum_{t=0}^{\infty} \beta^{t}\left[q_{t} u\left(c_{t}\right)-\left(1-q_{t}\right) v\left(\ell_{t}\right)\right]
$$

where $\beta \in(0,1)$ is the constant subjective discount factor, $q_{t}$ is a preference shock, and $u($.$) and v($.$) satisfy u^{\prime}()>0,. v^{\prime}()>0,. u^{\prime \prime}()<$.0 , and $v^{\prime \prime}()>$.0 .

\footnotetext{
${ }^{18}$ To make our points as clearly as possible, we will focus on perfect foresight equilibrium paths. This allows us to isolate variability in fiscal variables which is due solely to anticipated changes in fiscal revenues. In a stochastic version of this model, such changes would be reinforced by revisions to permanent revenues associated with unexpected shocks.
} 
The consumer's problem consists in choosing a sequence $\left\{c_{t}, \ell_{t}\right\}_{t=0}^{\infty}$ that maximizes (4.4) subject to (4.3), for a given path of $\left\{q_{t}, \theta_{t}, \alpha_{t}\right\}_{t=0}^{\infty} \cdot{ }^{19}$ In addition to (4.3), the first-order conditions for this problem are

$$
\begin{aligned}
& q_{t} u^{\prime}\left(c_{t}\right)=\lambda\left(1+\theta_{t}\right), \\
& \left(1-q_{t}\right) v^{\prime}\left(\ell_{t}\right)=\lambda \alpha_{t},
\end{aligned}
$$

for $t=0,1, \ldots$, where $\lambda$ is the Lagrange multiplier associated with constraint (4.3). Equation (4.5) states that, at an optimum, the marginal utility of consumption is proportional to the effective price of consumption, $1+\theta_{t}$. Similarly, equation (4.6) indicates that, at an optimum, the marginal disutility of labor is proportional to the marginal productivity of labor. ${ }^{20}$

As in any optimal fiscal policy problem, the allocation chosen by the government must be implementable as a competitive equilibrium. Hence, the household's optimality conditions will restrict the set of allocations that the government can choose from. There are two such "implementability" conditions. The first, intratemporal, is the equilibrium price function, $y^{\theta}\left(c_{t}, \ell_{t}\right)$, which expresses the consumption tax as a function of consumption and labor (as follows from (4.5) and (4.6)):

$$
\theta_{t} \equiv y^{\theta}\left(c_{t}, \ell_{t}\right)=\frac{\alpha_{t} q_{t} u^{\prime}\left(c_{t}\right)}{\left(1-q_{t}\right) v^{\prime}\left(\ell_{t}\right)}-1
$$

The second, intertemporal condition, is given by equation (4.6).

\subsection{The government's problem}

Consider now the policy problem faced by the government. In each period $t$, the government must finance government consumption, $g_{t}$, with either contemporaneous revenues or by borrowing in international capital markets. The government has two sources of revenues: it levies a consumption tax whose proceeds are given by $\theta_{t} c_{t}$, and owns a flow endowment of a tradable natural resource, whose value in each period $t$ is given by $z_{t}$. The government's flow budget constraint is thus

$$
b_{t}=(1+r) b_{t-1}+\theta_{t} c_{t}+z_{t}-g_{t},
$$

where $b_{t}$ denotes the government's holdings of net foreign assets at the end of period $t$. In what follows, $T_{t}\left(=\theta_{t} c_{t}\right)$ will denote consumption tax revenues and $R_{t}\left(=T_{t}+z_{t}\right)$ total revenues. Assuming away Ponzi games, the corresponding intertemporal budget constraint is given by

$$
(1+r) b_{-1}+\sum_{t=0}^{\infty}\left(\frac{1}{1+r}\right)^{t}\left(\theta_{t} c_{t}+z_{t}\right)=\sum_{t=0}^{\infty}\left(\frac{1}{1+r}\right)^{t} g_{t}
$$

Combining the consumer's and the government's intertemporal budget constraints (equations (4.3) and (4.9)) yields the economy's resource constraint (where $w(\equiv f+b)$ denotes the economy's net foreign assets):

\footnotetext{
${ }^{19} \mathrm{As}$ usual, and to eliminate inessentail dynamics, it will be assumed that $\beta=1 /(1+r)$.

${ }^{20}$ Naturally, in a decentralized competitive equilibrium, the real wage would equal $\alpha_{t}$.
} 


$$
(1+r) w_{-1}+\sum_{t=0}^{\infty}\left(\frac{1}{1+r}\right)^{t}\left(\alpha_{t} \ell_{t}+z_{t}\right)=\sum_{t=0}^{\infty}\left(\frac{1}{1+r}\right)^{t}\left(c_{t}+g_{t}\right)
$$

Government spending rule Our model departs from the standard optimal fiscal model à la Lucas and Stokey (1983) by assuming that government spending consists of both an exogenous component, $\bar{g}$, and an endogenous component. ${ }^{21}$ The endogenous component is assumed to be a non-negative, non-decreasing, and convex function of the primary surplus. Formally,

where the function $f(P S)$ satisfies ${ }^{22}$

$$
g_{t}=\bar{g}+f\left(P S_{t}\right)
$$

$$
f(.)>0, f^{\prime}(.)>0, f^{\prime \prime}(.)>0,
$$

and the primary surplus, $P S_{t}$, is defined as

$$
P S_{t} \equiv \theta_{t} c_{t}+z_{t}-g_{t}
$$

This specification includes as a special case (i.e., $f(P S) \equiv 0)$ the standard optimal fiscal policy problem in which government spending is taken as exogenous. We will refer to this case as the "Barro case" (after Barro (1979)), and use it as a benchmark. ${ }^{23}$

We view the spending rule (4.11) as reflecting a political distortion which characterizes the workings of actual economies. In a world with no political distortions, spending decisions would be made based solely on an evaluation of social costs and benefits, and would thus be independent of the business cycle (in terms of our model, they would be captured by the term $\bar{g}$ ). In actuality, however, decisions on public spending are heavily influenced by political pressures from various groups such as Congress, lobbyists, public sector workers' unions, government agencies, and states or provinces (see, for example, Olson (1971)). While such pressures are, to a greater or lesser extent, always present, they are more difficult to resist in good times than in bad times, as argued at length in Section 3. As a matter of political expediency, it is easier for a Finance Minister to dismiss spending pressures in times of deficit by simply pointing to the lack of resources. In contrast, when fiscal resources are abundant, spending pressures multiply and typically force the Finance Minister into yielding to some of the demands.

Before proceeding, some remarks on the formal specification of our government spending function are warranted. While the assumption that spending pressures are

\footnotetext{
${ }^{21}$ The exogenous component is assumed to be constant over time for expositional convenience and implies no loss of generality.

${ }^{22}$ Notice that while it may be natural to assume that there are no spending pressures when the primary surplus is zero (i.e., $f(0)=0$ ), we do not need to take a stand on the value of $f(0)$ for all of our results to go through.

${ }^{23}$ Notice that, in the Barro case, the government does not choose government spending since it becomes exogenous. Or, which is formally equivalent, it chooses government spending subject to the contraint that it be equal to $\bar{g}$
} 
an increasing function of available fiscal resources (as reflected in a higher primary balance) seems quite plausible, it might be less obvious why spending pressures may increase at an increasing rate. This assumption, however, is not implausible either. As argued in Section 3, spending pressures seem to multiply in response to revenue booms. Having said that, the convexity of the $f($.$) function is not necessary for our$ results to go through. If government consumption is included in the utility function (i.e., government consumption is a substitute for private consumption in utility terms, along the lines of Barro (1981)), a linear $f($.$) is all that is needed for the same results$ to obtain, as shown in Appendix E.

Ramsey allocations The government's optimization problem consists in choosing $\left\{c_{t}, \ell_{t}, g_{t}, \lambda\right\}$ to maximize (4.4) subject to (4.6), (4.9), (4.10), (4.11), with $\theta_{t}$ given by (4.7) and $P S_{t}$ by (4.13). ${ }^{24}$ The solution to the government's problem yields a system of equations which characterizes the perfect foresight equilibrium path of $\left\{c_{t}, \ell_{t}, g_{t}\right\}_{t=0}^{\infty}$ for given paths of $\left\{z_{t}, q_{t}, \alpha_{t}\right\}_{t=0}^{\infty}$ (see Appendix B). The optimal paths of $c_{t}$ and $\ell_{t}$ determine the optimal path of $\theta_{t}$ through the equilibrium price function (4.7).

To gain some insights, consider equation (B.1) of the solution system (see Appendix B), reproduced here for convenience:

$$
q_{t} u^{\prime}\left(c_{t}\right)=\mu-\frac{\partial y^{\theta}\left(c_{t}, \ell_{t}\right) c_{t}}{\partial c_{t}}\left[\frac{\gamma+\mu}{1+f^{\prime}\left(P S_{t}\right)}-\mu\right]
$$

where

$$
\begin{gathered}
\frac{\partial y^{\theta}\left(c_{t}, \ell_{t}\right) c_{t}}{\partial c_{t}}=\frac{\alpha_{t} q_{t} u^{\prime}\left(c_{t}\right)}{\left(1-q_{t}\right) v^{\prime}\left(l_{t}\right)}\left[1-\frac{1}{\eta^{c}\left(c_{t}\right)}\right]-1, \\
\eta^{c}\left(c_{t}\right) \equiv-\frac{\partial c_{t}}{\partial\left(1+\theta_{t}\right)} \frac{1+\theta_{t}}{c_{t}}=\frac{-u^{\prime}\left(c_{t}\right)}{c_{t} u^{\prime \prime}\left(c_{t}\right)}
\end{gathered}
$$

and $\gamma$ and $\mu$ denote the multipliers associated with constraints (4.9) and (4.10), respectively. Equation (4.16) defines the (absolute value of the) price elasticity of consumption. Equation (4.14) states that, at the optimum, the government equates the marginal utility of consumption, $q_{t} u^{\prime}\left(c_{t}\right)$, to its marginal cost. The latter is given by the marginal value of a unit of resources, $\mu$, minus the marginal value of the induced change in consumption tax revenues, given by the second term on the right-hand side of equation (4.14). Put differently, since an additional unit of consumption brings additional revenues, the marginal cost of consumption for the government is less than the marginal resource cost.

Equation (4.14) also makes clear the role of the political distortion. Other things being equal, an additional unit of consumption leads to higher revenues and hence a higher primary surplus. By increasing $f^{\prime}\left(P S_{t}\right)$ (recall that $f\left(P S_{t}\right)$ is convex), the higher primary surplus increases the fraction of additional revenues that will be lost to wasteful government spending. If $f(P S) \equiv 0$, the marginal value of the induced

\footnotetext{
${ }^{24}$ Notice that the government must choose a constant value of $\lambda$ to ensure that the optimal path of $\ell_{t}$ satisfies the implementability condition (4.6).
} 
change in revenues is simply $\gamma \frac{\partial y^{\theta}\left(c_{t}, \ell_{t}\right) c_{t}}{\partial c_{t}}$, which implies that there is no "leakage" of additional revenues through higher government spending.

The ensuing analysis will characterize the perfect foresight equilibrium paths of the endogenous variables for non-constant paths of the forcing processes. Thus, in our framework, volatility will be viewed as perfectly anticipated fluctuations in the paths of $\left\{z_{t}, q_{t}, \alpha_{t}\right\}$. Shocks to $z$ are meant to capture exogenous shocks to revenues, such as an increase in the world price of a primary commodity produced by a state-owned company. Shocks to $q$ affect consumption directly and will therefore be viewed as shocks to the tax base.

\section{The Barro case}

As a benchmark, it will prove useful to consider the particular case of (4.11) in which $f\left(P S_{t}\right) \equiv 0$. This is the standard case addressed in the optimal fiscal policy literature (see, for instance, Barro (1979) and Lucas and Stokey (1983)), in which the path of government spending is taken as exogenous. Our purpose in this section is to establish conditions under which full tax smoothing prevails. By doing so, we will ensure that deviations from the full tax smoothing policy in the general case (i.e., when $f(P S)$ satisfies (4.12)) will be due solely to the political distortion introduced by the spending rule (4.11).

\subsection{Full tax smoothing}

Our first result establishes sufficient conditions for optimal tax smoothing.

Proposition 1 (Barro rule). Suppose that $f\left(P S_{t}\right) \equiv 0$. If the price elasticity of consumption, $\eta^{c}\left(c_{t}\right)$, is constant, then along a perfect foresight equilibrium path, $\left\{\theta_{t}\right\}_{t=0}^{\infty}=\theta$, for any given paths of $\left\{z_{t}\right\}_{t=0}^{\infty},\left\{q_{t}\right\}_{t=0}^{\infty}$, and $\left\{\alpha_{t}\right\}_{t=0}^{\infty} \cdot{ }^{25}$

Proof. Set $f^{\prime}\left(P S_{t}\right)=0$ in (4.14) and substitute into it equations (4.5) and (4.6). Solve for $\theta$ to obtain:

$$
\theta_{t}=\frac{\mu-\lambda+\frac{\gamma}{\eta^{c}\left(c_{t}\right)}}{\lambda+\gamma\left[1-\frac{1}{\eta^{c}\left(c_{t}\right)}\right]} .
$$

If $\eta^{c}\left(c_{t}\right)$ is constant, then (5.1) implies that $\theta_{t}$ is constant along a perfect foresight equilibrium path $\square$

A class of utility functions that satisfies the condition that $\eta\left(c_{t}\right)$ be constant is

$$
u\left(c_{t}\right)=\frac{c_{t}^{1-\frac{1}{\rho}}}{1-\frac{1}{\rho}},
$$

in which case $\eta^{c}\left(c_{t}\right)=\rho$. In what follows, we will work with the iso-elastic family given by (5.2) to ensure that full tax smoothing holds in the Barro case and, therefore,

\footnotetext{
${ }^{25}$ Naturally, throughout our analysis we will implicitly restrict our attention to sequences of $\left\{z_{t}\right\}_{t=0}^{\infty}$ and $\left\{\alpha_{t}\right\}_{t=0}^{\infty}$ which lead to a finite present discounte value of resources, so that intertemporal constraints are well defined.
} 
that any deviations from the tax-smoothing rule will be due to the introduction of political distortions.

\subsection{Characterization of optimal policies}

We will now fully characterize the perfect foresight equilibrium outcome in the Barro case for a non-constant path of $z_{t}$ and $q_{t}$.

Proposition 2 (z-shocks in Barro case). Suppose that $\alpha_{t}=\alpha$ and $q_{t}=q$, for all $t \geq 0$. Consider a perfect foresight equilibrium path for an arbitrary path $\left\{z_{t}\right\}_{t=0}^{\infty}$. If , along such a path, $z_{t+1}>z_{t}$ for some $t$, then $c_{t+1}=c_{t}, \ell_{t+1}=\ell_{t}, \theta_{t+1}=\theta_{t}$, $T_{t+1}=T_{t}, R_{t+1}>R_{t}$, and $P S_{t+1}>P S_{t}$.

Proof. The results follow directly from equations (C.1)-(C.8) in Appendix C $\square$

A positive shock to revenues gets fully reflected in a higher primary surplus. Tax rates remain constant and, since there is no change in consumption, so do tax revenues. The volatility of total revenues has no impact on consumption and labor.

Proposition 3 (q-shocks in Barro case). Suppose that $z_{t}=z$ and $\alpha_{t}=\alpha$ for all $t \geq 0$. Consider a perfect foresight equilibrium path for an arbitrary path $\left\{q_{t}\right\}_{t=0}^{\infty}$. If, along such a path, $q_{t+1}>q_{t}$ for some $t$, then $c_{t+1}>c_{t}, \ell_{t+1}>\ell_{t}, \theta_{t+1}=\theta_{t}$, $T_{t+1}>T_{t}, R_{t+1}>R_{t}$, and $P S_{t+1}>P S_{t}$.

Proof. The results follow directly from equations (C.1)-(C.8) in Appendix $C \square$

By increasing the marginal utility of current consumption relative to both current leisure and future consumption, a higher $q$ leads to higher consumption. A higher $q$ should therefore be viewed as a positive shock to the tax base. Since the tax rate does not change, tax revenues increase proportionately with the increase in the tax base and are reflected one-to-one in a higher primary surplus. Furthermore, fluctuations in consumption and output only reflect the volatility of the environment (i.e., $q$-shocks).

In terms of the evidence reviewed in Section 2, the main implications for optimal fiscal policy that follow from the Barro rule are the following: (i) the correlation between the tax rate and the tax base should be zero; (ii) the correlation between government spending and the tax base should also be zero; ${ }^{26}$ (iii) the primary surplus moves one-to-one with the increase in tax revenues. As discussed in Section 2, these implications do not appear to fit the data. Introducing a political distortion will enable us to account for the observed empirical regularities.

\section{The f-case: the role of political distortions}

Consider now the case in which $f(P S)$ satisfies the conditions in (4.12).

\footnotetext{
${ }^{26}$ This implication is trivially true in this case because the path of government spending is exogenous and flat over time. However, the same implication follows if the level of public spending enters separably into the utility function and is optimally chosen by the government. In that case, the (endogenously-determined) level of $g$ is constant over time (see Appendix E).
} 
Proposition 4 (z-shocks in the f-case). Suppose that $\alpha_{t}=\alpha$ and $q_{t}=q$, for all $t \geq 0$. Consider a perfect foresight equilibrium path for an arbitrary path $\left\{z_{t}\right\}_{t=0}^{\infty}$. If, along such a path, $z_{t+1}>z_{t}$ for some $t$, then $c_{t+1}>c_{t}, \ell_{t+1}=\ell_{t}, g_{t+1}>g_{t}$, $\theta_{t+1}<\theta_{t}, T_{t+1}<T_{t}, R_{t+1}>R_{t}$, and $P S_{t+1}>P S_{t}$

Proof. See Appendix $D \square$

This proposition shows that when $z$ is temporarily high, the government finds it optimal to reduce tax rates and increase government spending. The optimal fiscal policy is thus procyclical: in good times (i.e., high $z$ ), the government increases public spending and lowers taxes; in bad times (i.e., low $z$ ), it reduces public spending and raises taxes. Moreover, the procyclicality of tax rates induces fluctuations in consumption, which rises in good times and falls in bad times. Such volatility in consumption, which is absent in the Barro case, is therefore not related to the underlying volatility of the environment, but to the government's policy response.

Why is procyclical fiscal policy optimal? Suppose that, in response to a temporarily higher $z$, the government did not change taxes (as in the Barro case). Then, the higher revenues would lead to a higher primary surplus and hence, by increasing government spending, to lower net tax revenues (recall the discussion following equation (4.14)). Therefore, the government reduces tax rates in an attempt to reduce the higher primary surplus and thus fend off spending pressures. However, the government will not find it optimal to fully offset the higher revenues by lowering taxes to the point of leaving the primary surplus unchanged. The reason is that the government must balance the trade-off between additional government spending and the intertemporal distortion implied by a non-constant path of taxes. The government thus absorbs a fraction of the positive shock in the form of higher spending. Since government spending increases and tax rates decline, the primary surplus rises by less than it would in the Barro case.

Three important remarks are called for concerning the nature of the result in Proposition 4. First, it should be clear that the procyclicality in government spending does not directly follow from the political pressures captured in $f($.$) . To see this,$ consider for a moment the case in which the government could resort to lump-sum taxes. In this case, as can be easily shown, the government would optimally choose to fully offset the effect of a higher $z$ on the primary surplus by reducing lump sum taxes. As a result, government spending would remain unchanged in response to an increase in $z$. Hence, the critical factor in explaining procyclical fiscal policy in our model is the interaction between political distortions and distortionary taxation in the presence of variable government revenues.

Second, our result does not hinge on government consumption providing no social benefits. The same result obtains in the alternative specification analyzed in Appendix $\mathrm{E}$ in which government consumption yields direct utility to the household and $f($.$) is a linear function. In this case, the higher primary surplus is still costly$ because, by increasing government consumption, it reduces at the margin the value of additional government consumption (due to diminishing marginal utility of government consumption).

Third, an additional (distortionary) tax would not change our results either. An example of this would be to add money into the model so that the government can 
also resort to the inflation tax. In that case, it can be shown that (if the government finds it optimal to use the inflation tax to begin with) it is optimal for the government to reduce both the consumption tax and the inflation tax in response to an increase in $z$. An additional distortionary tax simply provides the government with another means of reducing the higher primary surplus.

Consider now the optimal policy response to $q$-shocks, which capture shocks to the tax base.

Proposition 5 (q-shocks in the f-case). Suppose that $z_{t}=z$ and $\alpha_{t}=\alpha$ for all $t \geq 0$. Consider a perfect foresight equilibrium path for an arbitrary path $\left\{q_{t}\right\}_{t=0}^{\infty}$. If , along such a path, $q_{t+1}>q_{t}$, then $c_{t+1}>c_{t}, \ell_{t+1}>\ell_{t}, g_{t+1}>g_{t}, \theta_{t+1}<\theta_{t}$, $T_{t+1}>T_{t}, R_{t+1}>R_{t}$, and $P S_{t+1}>P S_{t}$.

Proof. See Appendix $D \square$

A temporary rise in $q$ leads to higher consumption and output. As in the case of an exogenous increase in revenues, the government responds to an increase in the tax base by lowering tax rates and increasing government spending. Such procyclical fiscal policy response exacerbates the fluctuations in consumption induced by the $q$ shock. Therefore, fluctuations in consumption do not only reflect the volatility of the environment but also the procyclical policy response to shocks. Political distortions, by inducing a procyclical fiscal policy, lead to larger economic fluctuations.

For further reference, note that, in terms of the evidence reviewed in Section 2, the predictions of the model are the following: (i) the correlation between the tax rate and the tax base should be negative; (ii) the correlation between government spending and the tax base should be positive; (iii) the primary surplus should increase by less than tax revenues.

Finally, it is worth stressing that in this model the procyclicality of fiscal policy does not originate in any sort of credit rationing during bad times on the part of international credit markets. Rather, it is the inability of the government to generate large budget surpluses in good times that leads to less borrowing in bad times relative to the amount of borrowing that would have taken place in the absence of political distortions. Hence, in the context of our model, it would be misleading to conclude that credit rationing in bad times by international markets is the driving force behind the existence of procyclical fiscal behavior in developing countries. This difference in emphasis has important public policy implications. In the credit rationing interpretation, policy efforts should be directed at removing those international credit markets distortions that may lie behind the rationing behavior in bad times. In our interpretation, policy efforts should be directed at implementing domestic institutional arrangements which ensure that government surpluses are saved in good times.

\section{Labor income taxation}

We now address the case of labor income taxation and derive the preference specification under which the same results obtain. Specifically, we show that when the utility function is defined in terms of labor and the sub-utility function for labor is 
iso-elastic, full tax smoothing is optimal in the Barro case and procyclical fiscal policy is optimal in the general case.

Formally, the household's and the government's intertemporal budget constraints become, respectively:

$$
\begin{aligned}
& (1+r) f_{-1}+\sum_{t=0}^{\infty}\left(\frac{1}{1+r}\right)\left(1-\tau_{t}\right) \alpha_{t} \ell_{t}=\sum_{t=0}^{\infty}\left(\frac{1}{1+r}\right)^{t} c_{t} \\
& (1+r) b_{-1}+\sum_{t=0}^{\infty}\left(\frac{1}{1+r}\right)^{t}\left(\tau_{t} \alpha_{t} \ell_{t}+z_{t}\right)=\sum_{t=0}^{\infty}\left(\frac{1}{1+r}\right)^{t} g_{t}
\end{aligned}
$$

where $\tau_{t}$ denotes the labor income tax.

Proceeding in the same way as above, the household's problem is first solved to derive the restrictions imposed by a competitive equilibrium. Such implementability conditions are then taken into account in the government's problem. Combining the first-order conditions for $\ell_{t}$ and $g_{t}$ from the government's problem, we obtain:

$$
\frac{\left(1-q_{t}\right) v^{\prime}\left(\ell_{t}\right)}{\alpha_{t}}=\mu+\frac{\partial y^{\tau}\left(c_{t}, \ell_{t}\right) \ell_{t}}{\partial \ell_{t}}\left[\frac{\gamma+\mu}{1+f^{\prime}\left(P S_{t}\right)}-\mu\right]
$$

where

$$
\begin{gathered}
\frac{\partial y^{\tau}\left(c_{t}, \ell_{t}\right) \ell_{t}}{\partial \ell_{t}}=1-\frac{\left(1-q_{t}\right) v^{\prime}\left(\ell_{t}\right)}{\alpha_{t} q_{t} u^{\prime}\left(c_{t}\right)}\left[1+\frac{1}{\eta^{\ell}\left(\ell_{t}\right)}\right], \\
\eta^{\ell}\left(\ell_{t}\right) \equiv \frac{\partial \ell_{t}}{\partial \alpha_{t}\left(1-\tau_{t}\right)} \frac{\alpha_{t}\left(1-\tau_{t}\right)}{\ell_{t}}=\frac{v^{\prime}\left(\ell_{t}\right)}{\ell_{t} v^{\prime \prime}\left(\ell_{t}\right)} .
\end{gathered}
$$

The equilibrium price function is denoted by $y^{\tau}\left(c_{t}, \ell_{t}\right)$ and the labor supply elasticity with respect to the after-tax real wage by $\eta^{\ell}\left(\ell_{t}\right)$.

As in the consumption tax case, we now establish sufficient conditions for optimal tax smoothing.

Proposition 6 (Barro rule). Suppose that $f\left(P S_{t}\right) \equiv 0$. If the labor supply elasticity, $\eta^{\ell}\left(\ell_{t}\right)$, is constant, then along a perfect foresight equilibrium path, $\left\{\tau_{t}\right\}_{t=0}^{\infty}=\tau$, for any given paths of $\left\{z_{t}\right\}_{t=0}^{\infty},\left\{q_{t}\right\}_{t=0}^{\infty}$, and $\left\{\alpha_{t}\right\}_{t=0}^{\infty}$

Proof. Set $f^{\prime}\left(P S_{t}\right)=0$ in (7.3) and substitute into it the consumer's first-order conditions. Solve for $\tau$ to obtain:

$$
\tau_{t}=\frac{\lambda-\mu+\frac{\gamma}{\eta^{\ell}\left(\ell_{t}\right)}}{\lambda+\gamma\left[1+\frac{1}{\eta^{\ell}\left(\ell_{t}\right)}\right]}
$$

If $\eta^{\ell}\left(\ell_{t}\right)$ is constant, then (7.5) implies that $\tau_{t}$ is constant along a perfect foresight equilibrium path $\square$ 
A class of utility functions that satisfies the condition that $\eta^{\ell}\left(\ell_{t}\right)$ be constant is

$$
v\left(\ell_{t}\right)=\frac{\ell_{t}^{1+\frac{1}{\sigma}}}{1+\frac{1}{\sigma}},
$$

in which case $\eta^{\ell}\left(\ell_{t}\right)=\sigma .^{27}$

Using (7.6), a set of propositions analogous to the consumption tax case can be derived for a non-constant path of $z_{t}$ and $q_{t}$. Given the symmetry between consumption and labor in our formulation, full-tax smoothing obtains in the Barro case and fiscal policy is procyclical in the general case (i.e., labor taxes fall and government spending increases in good times).

We now consider shocks to the marginal productivity of labor $(\alpha)$. Since labor supply will change in response to fluctuations in $\alpha$, these fluctuations constitute shocks to the tax base. $^{28}$

Proposition 7 (alpha-shocks). Suppose that $z_{t}=z$ and $q_{t}=q$ for all $t \geq 0$. Consider a perfect foresight equilibrium path for an arbitrary path $\left\{\alpha_{t}\right\}_{t=0}^{\infty}$. Suppose that, along such a path, $\alpha_{t+1}>\alpha_{t}$.

(i) If $f(P S) \equiv 0$ (the Barro case), $c_{t+1}=c_{t}, \ell_{t+1}>\ell_{t}, \tau_{t+1}=\tau_{t}, T_{t+1}>T_{t}$, $R_{t+1}>R_{t}$, and $P S_{t+1}>P S_{t}$.

(ii) If $f(P S)$ satisfies (4.12), then $c_{t+1}=c_{t}, \ell_{t+1}>\ell_{t}, g_{t+1}>g_{t}, \tau_{t+1}<\tau_{t}$, $T_{t+1}>T_{t}, R_{t+1}>R_{t}$, and $P S_{t+1}>P S_{t}$.

Proof. Proceeding analogously to the consumption-tax case (see Appendices $B$ and $C$ ), all the results follow $\square$

We have thus shown that, in the presence of a political distortion, a procyclical fiscal policy is optimal regardless of whether the tax system is income-based or consumption-based. In this context, therefore, the differences in the conduct of fiscal policy over the cycle observed in industrial and developing countries cannot be attributed to differences in the tax systems.

\section{Interpreting the evidence}

The evidence in Section 2 shows that, for the G-7 countries, the Barro rule seems to hold as a first approximation. In sharp contrast, fiscal policy in developing countries appears to be highly procyclical. How do we interpret such contrasting behavior of fiscal policy in light of our model?

It would be tempting to interpret the evidence for the G-7 countries as being consistent with the absence of political distortions (the Barro case) and the evidence for developing countries as being consistent with the presence of political distortions

\footnotetext{
${ }^{27}$ Notice that specifying the utility function in terms of leisure (as opposed to labor) would not deliver full tax smoothing. The reason is that if the utility function were defined as $u(c)+\frac{\left(1-\ell_{t}\right)^{1+\frac{1}{\sigma}}}{1+\frac{1}{\sigma}}$, the labor supply elasticity would not be constant.

${ }^{28}$ In the consumption tax case, $\alpha$-shocks have no impact on the tax-base due to the separability of the utility function.
} 
which put pressure on public spending in good times (the "f-case"). We would, however, argue against such interpretation since there is no reason to believe that the activity of political lobbying is limited to developing countries.

A second explanation could exploit the differences in tax systems: the G-7 tax system is, by and large, income-based, while in many developing countries the tax system is consumption-based. Any story along those lines, however, would be inconsistent with the model since the optimality of procyclical fiscal policy was shown not to depend on whether consumption or labor income taxes are used to finance public spending.

A third explanation - and the one that we favor - is based on the relative variability of tax bases in the G-7 countries and developing countries. As shown in Section 2 , the variability of the tax base in developing countries is more than twice as high (and more than three times as high if we took consumption as the relevant tax base) as that of the relevant tax base in the G-7 countries (i.e., output). In the model, to the extent that fluctuations in the tax base are small (i.e., fluctuations in the forcing processes are small), then political pressures to spend will be relatively unimportant because the budget surplus will deviate little from its average value (formally, the economy will be operating in a relatively flat portion of the f-curve). The Barro rule will thus hold as an approximation. In contrast, when fluctuations in the tax base are large, which implies generating large budget surpluses in good times, political pressures will be particularly acute. To avoid "excessive" spending induced by such pressures, policymakers will engage in a strongly procyclical fiscal policy. The inability to generate large enough surpluses in good times implies that fiscal policy will be highly contractionary in bad times. Hence, the larger are the fluctuations in the tax base, the more procyclical will be fiscal policy because it becomes increasingly costly to generate in good times the budget surpluses that would be necessary to achieve full tax smoothing.

Such an interpretation of the evidence is consistent with the scatter plots presented in Figures 1 and 2. Figure 1 illustrates that higher volatility (as measured by the standard deviation of output) is associated with a larger degree of procyclicality in government consumption (as measured by the correlation between the cyclical components of government purchases and output). Figure 2 shows that higher output volatility is associated with a larger degree of procyclicality in the inflation tax rate (as measured by the correlation between the cyclical components of the inflation tax rate and output). This supports the idea that the main driving force behind the degree of procyclicality of fiscal policy is the magnitude of the underlying variability of the tax base and is not necessarily related to the degree of a country's economic development. ${ }^{29}$

An additional channel that may explain differences in procyclicality across countries is that, for a given variability of the tax base, countries may differ in the intensity of the political pressures for additional spending that they face in good times, as re-

\footnotetext{
${ }^{29}$ Of course, correlation does not imply causality and, hence, causation could run in the opposite direction. In terms of Figure 1, for instance, discretionary changes in fiscal policy could lead to changes in economic activity and hence in the tax base. At this level of empiricism, we clearly cannot discard this possiblity.
} 
flected in a "steeper" slope of the $f$-function. Based on a sample of 26 Latin American countries, Stein, Talvi, and Grisanti (1999) find evidence that, after controlling for the volatility of the tax base, a higher level of political fragmentation leads to a more procyclical response of government spending.

\section{Conclusions}

While fiscal policy in the G-7 countries appears to follow Barro's optimal smoothing rules, fiscal policy in developing countries is highly procyclical. To explain this contrasting behavior, we develop an optimal fiscal policy model that incorporates a political distortion which makes it costly to run budget surpluses due to the pressures that abundant fiscal resources create to increase public spending. Specifically, we assume that there exists an endogenous component of government spending which is a positive function of the budget surplus (i.e., large surpluses give rise to spending pressures). Given this political distortion, a government that faces large (and perfectly anticipated) fluctuations in the tax base will choose to lower (increase) taxes and increase (lower) government spending in good times (bad times). In other words, our model predicts that, in the presence of this political distortion, optimal fiscal policy is procyclical.

The explanation for procyclicality offered in this paper contrasts sharply with the prevailing orthodoxy. The standard explanation for procyclical fiscal policy in developing countries relies on imperfect access during bad times to international credit markets. The idea is that countries hit by an adverse shock lose access to international credit at the time when it is most needed. From a public policy point of view, this interpretation calls for ensuring that developing countries - in particular those countries whose fundamentals are sound - retain access to international credit markets in bad times. In the aftermath of the global financial turmoil that followed the Russian crisis in the summer of 1998, several mechanisms have been proposed to achieve this objective, such as coordinated action between multilateral financial organizations and the private sector and contingent credit lines to be activated during bad times.

In our model, on the other hand, the procyclicality of fiscal policy does not originate in any international credit rationing during bad times. Rather, it is the inability of the government to generate large enough surpluses during expansions that forces it to borrow less during recessions - relative to a full-tax smoothing rule - in order to satisfy its solvency constraint. In this interpretation, the policy implications differ dramatically from those outlined above by shifting the emphasis from external financial constraints to domestic fiscal institutions. More specifically, the focus of public policy should be on designing fiscal arrangements aimed at ensuring that fiscal surpluses generated in good times are saved for a rainy day. An example of such fiscal arrangements are the current efforts by the Argentine government to implement a fiscal revenue stabilization fund whereby the central government would transfer to the provinces an amount of resources which is independent of the business cycle. By insulating revenue-sharing arrangements from cyclical fluctuations, the central government ought to be able to save during booms and dissave during recessions. More 
generally, von Hagen and Harden (1995) and Eichengreen, Hausmann, and von Hagen (1996) have proposed a "national fiscal council," an autonomous government institution - akin to an independent central bank - that would set the optimal amount of borrowing over the cycle.

\section{References}

[1] Aizenman, Joshua and Ricardo Hausmann, "The Impact of Inflation on Budgetary Discipline," NBER Working Paper No. 5338 (1995).

[2] Aizenman, Joshua, Michael Gavin, and Ricardo Hausmann, "Optimal Tax Policy with Endogenous Borrowing Constraint," NBER Working Paper No.5558 (1996).

[3] Alesina, A., and R. Perotti, "The Political Economy of Budget Deficits," NBER Working Paper No. 4637 (1994).

[4] Barro, Robert J., "On the Determination of Public Debt," Journal of Political Economy, Vol. 87 (1979), pp. 940-971.

[5] Barro, Robert J., "Output Effects of Government Purchases," Journal of Political Economy, Vol. 89 (1981), pp. 1086-1121.

[6] Barro, Robert J., "On the Predictability of Tax-Rate Changes," in Macroeconomic Policy (Cambridge, Mass.: Harvard University Press, 1990), pp. 268-297.

[7] Calvo, Guillermo and Pablo Guidotti, "On the Flexibility of Monetary Policy: The Case of the Optimal Inflation Tax," Review of Economic Studies, Vol. 60 (1993), pp. 667-687.

[8] Cooley, Thomas F., and Gary D. Hansen, "Money and the Business Cycle," in Thomas F. Cooley, ed., Frontiers of Business Cycle Research (Princeton, N.J.: Princeton University Press, 1995), pp. 175-216.

[9] Eichengreen, Barry, Ricardo Hausmann, and Jurgen von Hagen, "Reforming Fiscal Institutions in Latin America: The Case for a National Fiscal Council" (InterAmerican Development Bank, 1996), mimeo.

[10] Fiorito, Riccardo, "Stylized Facts of Government Finance in the G-7," IMF Working Paper no. 97/42 (1997).

[11] Fiorito, Riccardo, and Tryphon Kollintzas, "Stylized Facts of Business Cycles in the G7 from a Real Business Cycles Perspective," European Economic Review, Vol. 38 (1994), pp. 235-269.

[12] Gavin, Michael, and Roberto Perotti, "Fiscal Policy in Latin America," NBER Macroeconomics Annual (Cambridge, Mass.: MIT Press, 1997a), pp. 11-61.

[13] Gavin, Michael, and Roberto Perotti, "Fiscal Policy and Saving in Good Times and Bad Times," in Ricardo Haussman and Helmut Reisen, eds, Promoting Savings in Latin America (IDB and OECD, 1997b). 
[14] Gavin, Michael, Ricardo Hausmann, Roberto Perotti, and Ernesto Talvi, "Managing Fiscal Policy in Latin America," OCE Working Paper (Inter-American Development Bank, 1996).

[15] Gelb, Alan, Oil Windfalls: Blessing or Curse? (Washington, DC: The World Bank, 1989).

[16] Hercovitz, Zvi, and Michel Strawczynski, "Cyclical Bias in Government Spending: Evidence from the OECD" (Bank of Israel, 1998), mimeo.

[17] Huang, Chao-Hsi, and Kenneth S. Lin, "Deficits, Government Expenditures, and Tax Smoothing in the United States: 1929-1988," Journal of Monetary Economics, Vol. 31 (1993), pp. 317-339.

[18] Isham, Jonathan and Daniel Kaufmann, "The Forgotten Rationale For Policy Reform: The Productivity Of Investment Projects," (mimeo, World Bank, 1998), forthcoming in Quarterly Journal of Economics.

[19] Lane, PhillipR., "On the Cyclicality of Irish Fiscal Policy," Economic and Social Review, Vol. 29 (1998), pp. 1-17.

[20] Lane, Philip R., "The Cyclical Behaviour of Fiscal Policy: Evidence from the OECD" (Trinity College, Dublin, 1999), mimeo.

[21] Lane, Philip R., and Aaron Tornell, "Why Aren't Savings Rates in Latin America Procyclical?, Journal of Development Economics, Vol. 57 (1998), pp.185-199

[22] Little, I.M.D, Richard N. Cooper, W. Max Corden, and Sarath Rajapatirana, Boom, Crisis, and Adjustment: The Macroeconomic Experience of Developing Countries (Washington, DC: The World Bank, 1993).

[23] Lucas, Robert E., Jr, and Nancy L. Stokey, "Optimal Fiscal and Monetary Policy in an Economy without Capital," Journal of Monetary Economics, Vol. 12 (1983), pp. 55-93.

[24] Olson, Mancur, The Logic of Collective Action (Boston, Mass.: Harvard University Press, 1971).

[25] Persson, Torsten, "Comment on Gavin and Perotti," NBER Macroeconomics Annual (Cambridge, Mass.: MIT Press, 1997), pp. 61-67.

[26] Persson, Mats, Torsten Persson, and Lars Svensson, "Debt, Cash-Flow, and Inflation Incentives: A Swedish Example," NBER Working Paper No. 5772 (1996).

[27] Stein, Ernesto, Ernesto Talvi, and Alejandro Grisanti, "Institutional Arrangements and Fiscal Performance: The Latin American Experience," in James M. Poterba and Jurgen Von Hagen, eds., Fiscal Institutions and Fiscal Performance (Chicago: University of Chicago Press, 1999). 
[28] Strazicich, Mark C., "Does Tax Smoothing Differ by the Level of Government? Time Series Evidence from Canada and the United States," Journal of Macroeconomics, Vol. 19 (1997), pp. 305-326.

[29] Tornell, Aaron and Philip Lane, "Are windfalls a curse?," Journal of International Economics, Vol. 44 (1998), pp. 83-112.

[30] Tornell, Aaron and Philip Lane, "The voracity effect," American Economic Review, Vol. 89 (1999), pp. 22-46.

[31] Velasco, Andres, "A Model of Endogenous Fiscal Deficits and Delayed Fiscal Reforms," C.V. Starr Center for Applied Economics, Working paper No,. 93-04 (New York University, 1993).

[32] von Hagen, Jurgen, and I. Harden, "Budget Processes and Commitment to Fiscal Discipline," European Economic Review, Vol. 39 (1995), pp. 771-79. 


\section{APPENDICES}

\section{A. Business cycle properties of fiscal variables for individual countries}

This appendix reports for individual countries the aggregate statistics reported in Table 1 in the text (see Table A.1).

\section{B. The Ramsey system}

The following system, which results from the Ramsey problem outlined in the text, characterizes the economy's perfect-foresight equilibrium path for any given paths $\left\{z_{t}\right\}_{t=0}^{\infty},\left\{q_{t}\right\}_{t=0}^{\infty}$, and $\left\{\alpha_{t}\right\}_{t=0}^{\infty}$ :

$$
\begin{gathered}
q_{t} u^{\prime}\left(c_{t}\right)=\mu-\frac{\partial y^{\theta}\left(c_{t}, \ell_{t}\right) c_{t}}{\partial c_{t}}\left[\frac{\gamma+\mu}{1+f^{\prime}\left(P S_{t}\right)}-\mu\right] \\
\left(1-q_{t}\right) v^{\prime}\left(\ell_{t}\right)=\alpha_{t} \mu+c_{t} \frac{\partial y^{\theta}\left(c_{t}, \ell_{t}\right)}{\partial \ell_{t}}\left(\frac{\gamma+\mu}{1+f^{\prime}\left(P S_{t}\right)}-\mu\right)+\delta_{t}\left(1-q_{t}\right) \frac{v^{\prime \prime}\left(\ell_{t}\right)}{\alpha_{t}} \\
\Omega_{t}=\frac{\gamma+\mu}{1+f^{\prime}\left(P S_{t}\right)} \\
\sum_{0}^{\infty} \beta^{t} \delta_{t}=0 \\
(1+r) b_{-1}+\sum_{t=0}^{\infty}\left(\frac{1}{1+r}\right)^{t}\left(\theta_{t} c_{t}+z_{t}-g_{t}\right)=0 \\
(1+r) w_{-1}+\sum_{t=0}^{\infty}\left(\frac{1}{1+r}\right)^{t}\left(\alpha_{t} \ell_{t}-c_{t}+z_{t}-g_{t}\right)=0 \\
g_{t}=\bar{g}+f\left(P S_{t}\right) \\
q_{t} u^{\prime}\left(c_{t}\right)=\lambda\left(1+\theta_{t}\right) \\
\left(1-q_{t}\right) v^{\prime}\left(\ell_{t}\right)=\lambda \alpha_{t} \\
P S_{t} \equiv \theta_{t} c_{t}+z_{t}-g_{t}
\end{gathered}
$$

where $\frac{\partial y^{\theta}\left(c_{t}, \ell_{t}\right) c_{t}}{\partial c_{t}}$ is given by equation (4.15); $\frac{\partial y^{\theta}\left(c_{t}, \ell_{t}\right)}{\partial \ell_{t}}$ follows from (4.7); and $\gamma, \mu$, $\Omega_{t}$, and $\delta_{t}$ denote the multipliers associated with constraints (4.9), (4.10), (4.11), and (4.6), respectively. The solution to this system yields optimal paths for $\left\{c_{t}, \ell_{t}, g_{t}, \Omega_{t}, \delta_{t}, \theta_{t}, P S_{t}\right\}_{t=0}^{\infty}$ and optimal constant values for $\gamma, \mu$, and $\lambda$. 


\section{The Barro system}

This appendix characterizes the perfect-foresight equilibrium paths for the Barro case (i.e., the case corresponding to $f(.) \equiv 0$ ) for any arbitrary paths $\left\{z_{t}\right\}_{t=0}^{\infty},\left\{q_{t}\right\}_{t=0}^{\infty}$, and $\left\{\alpha_{t}\right\}_{t=0}^{\infty}$. The sub-utility function for consumption takes the iso-elastic form given by $(5.2)$.

The system The perfect-foresight equilibrium path is fully described by the following system of eight equations:

$$
\begin{gathered}
\theta_{t}=\frac{\mu-\lambda+\frac{\gamma}{\rho}}{\lambda+\gamma\left(1-\frac{1}{\rho}\right)} \\
\left(1-q_{t}\right) v^{\prime}\left(\ell_{t}\right)=\alpha_{t} \mu+\gamma c_{t} \frac{\partial y^{\theta}\left(c_{t}, \ell_{t}\right)}{\partial \ell_{t}}+\delta_{t}\left(1-q_{t}\right) \frac{v^{\prime \prime}\left(\ell_{t}\right)}{\alpha_{t}} \\
\sum_{0}^{\infty} \beta^{t} \delta_{t}=0 \\
(1+r) b_{-1}+\sum_{t=0}^{\infty}\left(\frac{1}{1+r}\right)^{t}\left(\theta_{t} c_{t}+z_{t}-\bar{g}\right)=0 \\
(1+r) w_{-1}+\sum_{t=0}^{\infty}\left(\frac{1}{1+r}\right)^{t}\left(\alpha_{t} \ell_{t}-c_{t}+z_{t}-\bar{g}\right)=0 \\
q_{t} c_{t}^{-\frac{1}{\rho}}=\lambda\left(1+\theta_{t}\right) \\
\left(1-q_{t}\right) v^{\prime}\left(\ell_{t}\right)=\lambda \alpha_{t} \\
P S_{t} \equiv \theta_{t} c_{t}+z_{t}-\bar{g}
\end{gathered}
$$

where

$$
\frac{\partial y^{\theta}\left(c_{t}, \ell_{t}\right)}{\partial \ell_{t}}=\left(1+\theta_{t}\right)\left(1-\frac{1}{\rho}\right)-1
$$

Equilibrium paths From (C.1), and (C.7), respectively, it follows that:

$$
\begin{aligned}
& \theta_{t}=\tilde{\theta}(\lambda, \mu, \gamma), \\
& \ell_{t}=\tilde{\ell}\left(\lambda ; q_{t}, \alpha_{t}\right),
\end{aligned}
$$

where a sign below a forcing variable indicates the sign of the "partial derivative" (i.e., how, say, $\ell_{t}$ changes relative to $\ell_{t-1}$ when $q_{t}$ increases relative to $q_{t-1}$ ).

Equations (C.6) and (C.10) imply: 


$$
c_{t}=\tilde{c}\left(\lambda, \mu, \gamma ; \underset{+}{q_{t}}\right)
$$

From (C.8), (C.10) and (C.11), it follows that

$$
P S_{t}=\widetilde{P S}_{t}\left(\lambda, \mu, \gamma ; \underset{+}{q_{t}, z_{t}}\right) .
$$

Finally, from (C.10) and (C.11):

$$
\begin{gathered}
T_{t} \equiv \theta_{t} c_{t}=\tilde{T}\left(\lambda, \mu, \gamma ; \underset{+}{q_{t}}\right), \\
R_{t} \equiv \theta_{t} c_{t}+z_{t}=\tilde{R}\left(\lambda, \mu, \gamma ; \underset{+}{q_{t}, z_{t}}\right) .
\end{gathered}
$$

\section{The f-system}

In this case, the system describing a perfect foresight equilibrium path consists of ten equations. Substitute (B.8) into (B.1) and solve for $\theta_{t}$ from equation (B.1), taking into account (5.2), to obtain:

$$
\theta_{t}=\frac{\mu-\lambda+\frac{1}{\rho}\left(\frac{\gamma+\mu}{1+f^{\prime}\left(P S_{t}\right)}-\mu\right)}{\lambda+\left(1-\frac{1}{\rho}\right)\left(\frac{\gamma+\mu}{1+f^{\prime}\left(P S_{t}\right)}-\mu\right)}
$$

The rest of the system is given by equations (B.2)-(B.10).

In order to prove Propositions 4 and 5, it will prove useful to first show the following claims.

Fact 1 At an optimum, $\frac{\partial y^{\theta}\left(c_{t}, \ell_{t}\right) c_{t}}{\partial c_{t}}=\theta\left(1-\frac{1}{\rho}\right)-\frac{1}{\rho}<0$. To see this, notice that this is a statement about the Laffer curve. Indeed, taking into account (5.2) and (B.6), it is easy to show that the tax rate that maximizes tax revenues is given by $\theta=\frac{1}{\rho-1}$. This implies that, at an optimum, $\theta<\frac{1}{\rho-1}$. If this were not the case, the government could obtain the same amount of revenues with a lower $\theta$ (which implies higher consumption), which is clearly not optimal. Given that $\theta<\frac{1}{\rho-1}$, it immediately follows that $\theta\left(1-\frac{1}{\rho}\right)-\frac{1}{\rho}<0$.

Fact 2 Along a perfect foresight equilibrium path, $\theta$ and $P S$ move in opposite directions. To see this, totally differentiate (D.1) and substitute for $\lambda$ from (D.1) to obtain:

$$
\frac{d \theta}{d P S}=\frac{f^{\prime \prime}(P S)(\gamma+\mu)^{2}}{(1+\theta)\left[\lambda+\left(1-\frac{1}{\rho}\right)\left(\frac{\gamma+\mu}{1+f^{\prime}\left(P S_{t}\right)}-\mu\right)\right]^{2}\left[1+f^{\prime \prime}(P S)\right]^{3}}\left[\theta\left(1-\frac{1}{\rho}\right)-\frac{1}{\rho}\right]<0,
$$

where the right-most inequality follows from Fact 1. 
Fact 3 Consumption tax revenues are an increasing function of both $\theta$ and $q$. To see this, note, using (5.2) and (B.8) that $(\theta c)=\rho \hat{q}+\frac{\hat{\theta}}{1+\theta}(1+\theta-\rho \theta)$. Since, by Fact $1,1+\theta-\rho \theta>0$, the claim holds.

Proof of Proposition 4. We first show that if, along a perfect foresight equilibrium path, $z_{t+1}>z_{t}$, then $\theta_{t+1}<\theta_{t}$. The proof proceeds by contradiction.

(i) Suppose $\theta_{t+1}=\theta_{t}$. Then, by Fact 2, $P S_{t+1}=P S_{t}$. This implies, by (B.7), that $g_{t+1}=g_{t}$. In addition, by (B.8), $\theta_{t+1}=\theta_{t}$ implies that $c_{t+1}=c_{t}$ and therefore $\theta_{t+1} c_{t+1}=\theta_{t} c_{t}$. Since $\theta_{t+1} c_{t+1}=\theta_{t} c_{t}, z_{t+1}>z_{t}$, and $g_{t+1}=g_{t}$, then, by (B.10), $P S_{t+1}>P S_{t}$, which is a contradiction.

(ii) Suppose $\theta_{t+1}>\theta_{t}$. Then, by Fact $2, P S_{t+1}<P S_{t}$. This implies, by (B.7), that $g_{t+1}<g_{t}$. In addition, $\theta_{t+1}>\theta_{t}$ implies that $\theta_{t+1} c_{t+1}>\theta_{t} c_{t}$ by Fact 3 . Since $\theta_{t+1} c_{t+1}>\theta_{t} c_{t}, z_{t+1}>z_{t}$, and $g_{t+1}<g_{t}$, then, by (B.10), $P S_{t+1}>P S_{t}$, which is a contradiction.

We have thus shown that when $z_{t+1}>z_{t}$, then $\theta_{t+1}<\theta_{t}$. By Fact 2, $P S_{t+1}>$ $P S_{t}$. Then, by (B.7), it follows that $g_{t+1}>g_{t}$. Since $\theta_{t+1}<\theta_{t}$, then by (B.8), $c_{t+1}>$ $c_{t}$. Since $\theta_{t+1}<\theta_{t}$, by Fact $3, \theta_{t+1} c_{t+1}<\theta_{t} c_{t}$. Since $z_{t+1}>z_{t}, P S_{t+1}>P S_{t}$, and $g_{t+1}>g_{t}$, then $R_{t+1}>R_{t} \square$

Proof of Proposition 5. We first show that if, along a perfect foresight equilibrium path, $q_{t+1}>q_{t}$, then $\theta_{t+1}<\theta_{t}$. The proof proceeds by contradiction.

(i) Suppose $\theta_{t+1}=\theta_{t}$. Then, by Fact $2, P S_{t+1}=P S_{t}$. This implies, by (B.7), that $g_{t+1}=g_{t}$. In addition, by (B.8), $q_{t+1}>q_{t}$ implies that $c_{t+1}>c_{t}$ and therefore $\theta_{t+1} c_{t+1}>\theta_{t} c_{t}$. Since $\theta_{t+1} c_{t+1}>\theta_{t} c_{t}$ and $g_{t+1}=g_{t}$, then, by (B.10), $P S_{t+1}>P S_{t}$, which is a contradiction.

(ii) Suppose $\theta_{t+1}>\theta_{t}$. Then, by Fact 2, $P S_{t+1}<P S_{t}$. This implies, by (B.7), that $g_{t+1}<g_{t}$. In addition, since $q_{t+1}>q_{t}$ and $\theta_{t+1}>\theta_{t}$, then, by Fact $3, \theta_{t+1} c_{t+1}>\theta_{t} c_{t}$. Since $\theta_{t+1} c_{t+1}>\theta_{t} c_{t}$ and $g_{t+1}<g_{t}$, then, by (B.10), $P S_{t+1}>P S_{t}$, which is a contradiction.

We have thus shown that when $q_{t+1}>q_{t}$, then $\theta_{t+1}<\theta_{t}$. By Fact 2, $P S_{t+1}>$ $P S_{t}$. Then, by (B.7), $g_{t+1}>g_{t}$. Since $P S_{t+1}>P S_{t}$ and $g_{t+1}>g_{t}$, it follows from (B.10) that $\theta_{t+1} c_{t+1}>\theta_{t} c_{t}$. Since $q_{t+1}>q_{t}$ and $\theta_{t+1}<\theta_{t}$, then by (B.8), $c_{t+1}>c_{t}$. Finally, since $q_{t+1}>q_{t}, \ell_{t+1}>\ell_{t} \square$

\section{E. Government spending in the utility function}

This appendix shows that our main result that the optimal fiscal policy is procyclical in the presence of variable fiscal revenues also obtains in a model in which government consumption enters into the utility function and $f($.$) is a linear function (i.e., f^{\prime}($.) is a positive constant).

Suppose that the utility function is now given by

$$
\sum_{t=0}^{\infty} \beta^{t}\left[q_{t} u\left(c_{t}\right)-\left(1-q_{t}\right) v\left(\ell_{t}\right)+z\left(g_{t}\right)\right]
$$


where $z(g)$ is a strictly increasing and strictly concave function. The household maximizes (E.1), taking $g_{t}$ as given, subject to (4.3). The household's first-order conditions remain unchanged and are given by (4.5) and (4.6).

The government's problem consists in maximizing (E.1) subject to the same constraints as before, given by (4.6), (4.9), (4.10), (4.11), with $\theta_{t}$ given by (4.7) and $P S_{t}$ by (4.13). The resulting system is the same as in the f-case above (given by (B.1)-(B.10)), except for (B.1) and (B.3) which are replaced by, respectively,

$$
\begin{gathered}
\theta_{t}=\frac{\mu-\lambda+\frac{1}{\rho} A\left(g_{t}\right)}{\lambda+\left(1-\frac{1}{\rho}\right) A\left(g_{t}\right)} \\
\Omega_{t}=\frac{\gamma+\mu-z^{\prime}\left(g_{t}\right)}{1+f^{\prime}\left(P S_{t}\right)}
\end{gathered}
$$

where

$$
\begin{aligned}
A\left(g_{t}\right) & \equiv \frac{\gamma+\mu}{1+f^{\prime}\left(P S_{t}\right)}-\mu+\frac{f^{\prime}\left(P S_{t}\right)}{1+f^{\prime}\left(P S_{t}\right)} z^{\prime}\left(g_{t}\right), \\
A^{\prime}\left(g_{t}\right) & \equiv \frac{f^{\prime}\left(P S_{t}\right)}{1+f^{\prime}\left(P S_{t}\right)} z^{\prime \prime}\left(g_{t}\right)<0,
\end{aligned}
$$

and $f^{\prime}\left(P S_{t}\right)$ is some positive constant.

In this formulation, the Barro case corresponds to the case in which $\Omega_{t} \equiv 0$ for all $t$ (i.e., the government does not face constraint (4.11)) and $f(.) \equiv 0$. In this case, as can be easily shown, the system remains the same as in the Barro case described in Appendix $\mathrm{C}$ with an additional equation given by $z^{\prime}\left(g_{t}\right)=\gamma+\mu$. This equation implies that $g_{t}$ is constant along a perfect foresight equilibrium path regardless of the path of the forcing variables $z_{t}, q_{t}$, and $\alpha_{t}$. Hence, Propositions (2) and (3) hold in this case as well with the added implication that the path of $g_{t}$ is endogenously determined and remains flat over time.

To show the main results, we need to proceed in the same way as before. We first show the following:

Fact 4. Along a perfect foresight equilibrium path, there exists a negative relationship between $\theta$ and $g$. To this effect, totally differentiate (E.2) to obtain

$$
\frac{d \theta}{d g}=\frac{-A^{\prime}\left(g_{t}\right)}{(1+\theta)\left[\lambda+\left(1-\frac{1}{\rho}\right) A\left(g_{t}\right)\right]^{2}}\left[\frac{\gamma+\mu}{1+f^{\prime}\left(P S_{t}\right)}+z^{\prime}\left(g_{t}\right) \frac{f^{\prime}\left(P S_{t}\right)}{1+f^{\prime}\left(P S_{t}\right)}\right]\left[\theta\left(1-\frac{1}{\rho}\right)-\frac{1}{\rho}\right]<0
$$

where the right-most inequality follows from Fact 2 above - which still applies in this case - and the fact that $A^{\prime}\left(g_{t}\right)<0$.

Proposition 8. Suppose that $\alpha_{t}=\alpha$ and $q_{t}=q$, for all $t \geq 0$. Consider a perfect foresight equilibrium path for an arbitrary path $\left\{z_{t}\right\}_{t=0}^{\infty}$. If , along such a path, 
$z_{t+1}>z_{t}$ for some $t$, then $c_{t+1}>c_{t}, \ell_{t+1}=\ell_{t}, g_{t+1}>g_{t}, \theta_{t+1}<\theta_{t}, T_{t+1}<T_{t}$, $R_{t+1}>R_{t}$, and $P S_{t+1}>P S_{t}$.

Proof. We first show that if, along a perfect foresight equilibrium path, $z_{t+1}>z_{t}$, then $\theta_{t+1}<\theta_{t}$. The proof proceeds by contradiction.

(i) Suppose $\theta_{t+1}=\theta_{t}$. Then, by Fact $4, g_{t+1}=g_{t}$. This implies, by (B.7), that $P S_{t+1}=P S_{t}$. In addition, by (B.8), $\theta_{t+1}=\theta_{t}$ implies that $c_{t+1}=c_{t}$ and therefore $\theta_{t+1} c_{t+1}=\theta_{t} c_{t}$. Since $\theta_{t+1} c_{t+1}=\theta_{t} c_{t}, z_{t+1}>z_{t}$, and $g_{t+1}=g_{t}$, then, by (B.10), $P S_{t+1}>P S_{t}$, which is a contradiction.

(ii) Suppose $\theta_{t+1}>\theta_{t}$. Then, by Fact 4, $g_{t+1}<g_{t}$. This implies, by (B.7), that $P S_{t+1}<P S_{t}$. In addition, $\theta_{t+1}>\theta_{t}$ implies that $\theta_{t+1} c_{t+1}>\theta_{t} c_{t}$ by Fact 3. Since $\theta_{t+1} c_{t+1}>\theta_{t} c_{t}, z_{t+1}>z_{t}$, and $g_{t+1}<g_{t}$, then, by (B.10), $P S_{t+1}>P S_{t}$, which is a contradiction.

We have thus shown that when $z_{t+1}>z_{t}$, then $\theta_{t+1}<\theta_{t}$. By Fact $4, g_{t+1}>g_{t}$. Then, by (B.7), it follows that $g_{t+1}>g_{t}$. Since $\theta_{t+1}<\theta_{t}$, then by (B.8), $c_{t+1}>c_{t}$. Since $\theta_{t+1}<\theta_{t}$, by Fact $3, \theta_{t+1} c_{t+1}<\theta_{t} c_{t}$. Since $z_{t+1}>z_{t}, P S_{t+1}>P S_{t}$, and $g_{t+1}>g_{t}$, then $R_{t+1}>R_{t} \square$

Proposition 9. Suppose that $z_{t}=z$ and $\alpha_{t}=\alpha$ for all $t \geq 0$. Consider a perfect foresight equilibrium path for an arbitrary path $\left\{q_{t}\right\}_{t=0}^{\infty}$. If , along such a path, $q_{t+1}>q_{t}$ for some $t$, then $c_{t+1}>c_{t}, \ell_{t+1}>\ell_{t}, g_{t+1}>g_{t}, \theta_{t+1}<\theta_{t}, T_{t+1}>T_{t}$, $R_{t+1}>R_{t}$, and $P S_{t+1}>P S_{t}$.

Proof. We first show that if, along a perfect foresight equilibrium path, $q_{t+1}>q_{t}$, then $\theta_{t+1}<\theta_{t}$. The proof proceeds by contradiction.

(i) Suppose $\theta_{t+1}=\theta_{t}$. Then, by Fact $4, g_{t+1}=g_{t}$. This implies, by (B.7), that $P S_{t+1}=P S_{t}$. In addition, by (B.8), $q_{t+1}>q_{t}$ implies that $c_{t+1}>c_{t}$ and therefore $\theta_{t+1} c_{t+1}>\theta_{t} c_{t}$. Since $\theta_{t+1} c_{t+1}>\theta_{t} c_{t}$ and $g_{t+1}=g_{t}$, then, by $(B .10), P S_{t+1}>P S_{t}$, which is a contradiction.

(ii) Suppose $\theta_{t+1}>\theta_{t}$. Then, by Fact $4, g_{t+1}<g_{t}$. This implies, by (B.7), that $P S_{t+1}<P S_{t}$. In addition, since $q_{t+1}>q_{t}$ and $\theta_{t+1}>\theta_{t}$, then by Fact 3 $\theta_{t+1} c_{t+1}>\theta_{t} c_{t}$. Since $\theta_{t+1} c_{t+1}>\theta_{t} c_{t}$ and $g_{t+1}<g_{t}$, then, by (B.10), $P S_{t+1}>P S_{t}$, which is a contradiction.

We have thus shown that when $q_{t+1}>q_{t}$, then $\theta_{t+1}<\theta_{t}$. By Fact $4, g_{t+1}>g_{t}$. Then, by (B.7), $P S_{t+1}>P S_{t}$. Since $P S_{t+1}>P S_{t}$ and $g_{t+1}>g_{t}$, it follows from (B.10) that $\theta_{t+1} c_{t+1}>\theta_{t} c_{t}$. Since $q_{t+1}>q_{t}$ and $\theta_{t+1}<\theta_{t}$, then by (B.8), $c_{t+1}>c_{t}$. Finally, since $q_{t+1}>q_{t}, \ell_{t+1}>\ell_{t} \square$ 
TABLE 1: Business Cycle Properties of Fiscal Variables

\begin{tabular}{|c|c|c|c|c|c|c|c|}
\hline \multirow[b]{2}{*}{ Country } & \multirow{2}{*}{$\begin{array}{l}\text { Number of } \\
\text { countries }\end{array}$} & \multicolumn{2}{|c|}{ Standard deviation } & \multicolumn{4}{|c|}{ Correlations with output } \\
\hline & & Output & Priv. cons. & Priv. cons. & Gov. cons. & Revenues & Inflation tax \\
\hline Industrial countries & 20 & 2.18 & 2.85 & 0.79 & $\begin{array}{l}0.17^{\star \star} \\
(2.47)\end{array}$ & $\begin{array}{c}0.38^{\star \star \star} \\
(5.61)\end{array}$ & $\begin{array}{c}0.23^{\star \star \star} \\
(4.76)\end{array}$ \\
\hline G-7 & 6 & 2.05 & 2.26 & 0.87 & $\begin{array}{c}-0.02 \\
(-0.28)\end{array}$ & $\begin{array}{l}0.31^{* *} \\
(3.20)\end{array}$ & $\begin{array}{l}0.25^{\star * *} \\
(4.85)\end{array}$ \\
\hline Other Industrial & 14 & 2.24 & 3.10 & 0.75 & $\begin{array}{l}0.25^{\star *} \\
(2.95)\end{array}$ & $\begin{array}{c}0.39^{\star \star \star} \\
(4.59)\end{array}$ & $\begin{array}{l}0.22^{\star \star *} \\
(3.33)\end{array}$ \\
\hline Developing Countries & 36 & 4.47 & 7.62 & 0.60 & $\begin{array}{l}0.53^{\star \star \star} \\
(15.40)\end{array}$ & $\begin{array}{l}0.53^{\star \star \star} \\
(14.33)\end{array}$ & $\begin{array}{l}-0.09^{\star} \\
(-1.86)\end{array}$ \\
\hline Latin America & 17 & 4.54 & 7.41 & 0.64 & $\begin{array}{c}0.53^{* * *} \\
(9.79)\end{array}$ & $\begin{array}{l}0.49^{\star \star *} \\
(10.71)\end{array}$ & $\begin{array}{c}-0.19^{\star *} \\
(-2.86)\end{array}$ \\
\hline Africa & 11 & 4.00 & 8.46 & 0.48 & $\begin{array}{c}0.54^{\star \star \star} \\
(9.60)\end{array}$ & $\begin{array}{c}0.55^{\star \star \star} \\
(8.19)\end{array}$ & $\begin{array}{l}-0.10 \\
(-1.41)\end{array}$ \\
\hline Other Developing & 8 & 4.96 & 6.91 & 0.69 & $\begin{array}{c}0.52^{\star \star \star} \\
(6.59)\end{array}$ & $\begin{array}{c}0.62^{\star \star \star} \\
(5.72)\end{array}$ & $\begin{array}{c}0.10 \\
(0.77)\end{array}$ \\
\hline All sample & 56 & 3.65 & 5.92 & 0.69 & $\begin{array}{l}0.40^{\star \star *} \\
(10.01)\end{array}$ & $\begin{array}{l}0.47^{\star \star \star} \\
(13.44)\end{array}$ & $\begin{array}{c}0.02 \\
(0.53)\end{array}$ \\
\hline
\end{tabular}

NOTE: All variables (except for the inflation tax) are expressed in real terms. The inflation tax is defined as the inflation rate over one plus the inflation rate. Statistics are based on Hodrick-Prescott filtered data. The sample period is 1970-1994. Data are annual from IFS and GFS of the IMF, except for Argentina, Bolivia, Brazil, Dominican Republic, and Peru, which are from the IADB's internal database. t-statistics in parentheses. One, two, and three stars indicate significance at the 10,5 , and 1 percent level, respectively. 
Table 2: Oil Boom and Aggregate Expenditures, 1974-1978

\begin{tabular}{|c|c|c|c|c|c|c|c|c|c|}
\hline & \multicolumn{8}{|c|}{ Windfall gain } & \\
\hline & \multirow{5}{*}{$\begin{array}{c}\text { (percent } \\
\text { of GDP) }\end{array}$} & \multicolumn{8}{|c|}{ (percent of windfall gain) } \\
\hline & & \multirow{4}{*}{\begin{tabular}{|c|} 
Total \\
$(1)+(2)+(3)$ \\
\end{tabular}} & \multicolumn{6}{|c|}{ Spent } & \multirow{4}{*}{$\begin{array}{r}\text { Saved } \\
\text { (3) }\end{array}$} \\
\hline & & & \multicolumn{3}{|c|}{ Private expenditures } & \multicolumn{3}{|c|}{ Public expenditures } & \\
\hline & & & Cons. & Invest. & Total & Cons. & Invest. & Total & \\
\hline & & & & & $(1)$ & & & (2) & \\
\hline Algeria & 27.1 & 100.0 & 13.3 & NA & 13.3 & 5.2 & 97.4 & 102.6 & -15.9 \\
\hline Ecuador & 16.7 & 100.0 & -5.4 & 22.8 & 17.4 & 32.9 & 28.7 & 61.7 & 21.0 \\
\hline Indonesia & 16.0 & 100.0 & 13.1 & -10.6 & 2.5 & 15.0 & 49.4 & 64.4 & 33.1 \\
\hline Iran & 36.9 & 100.0 & -19.0 & 18.2 & -0.8 & 27.6 & 27.1 & 54.7 & 46.1 \\
\hline Nigeria & 22.8 & 100.0 & 12.7 & -28.9 & -16.2 & 18.4 & 85.5 & 103.9 & 12.3 \\
\hline Venezuela & 10.7 & 100.0 & 17.8 & 30.8 & 48.6 & 15.0 & 45.8 & 60.7 & -9.3 \\
\hline Average & 21.7 & 100.0 & 2.0 & 5.1 & 6.2 & 19.4 & 56.5 & 75.9 & 17.9 \\
\hline
\end{tabular}

Source: Based on Gelb (1989) 
Table 3: Oil Boom and Fiscal Response, 1974-1978

(percent of GDP)

\begin{tabular}{|c|c|c|c|c|c|}
\hline & \multicolumn{2}{|c|}{ Total Revenues } & \multicolumn{2}{|c|}{ Total Expenditures } & \multirow{2}{*}{$\begin{array}{l}\text { Marginal propensity to } \\
\text { spend out of revenues }\end{array}$} \\
\hline & $1970-1972$ & 1974-1978 & $1970-1972$ & 1974-1978 & \\
\hline Algeria & 32.6 & 59.9 & 40.2 & 71.5 & 0.97 \\
\hline Ecuador & 14.2 & 12.9 & 14.1 & 14.4 & NA \\
\hline Indonesia & 15.6 & 23.1 & 18.7 & 25.0 & 0.90 \\
\hline Iran & 31.7 & 71.1 & 37.7 & 71.6 & 0.85 \\
\hline Nigeria & 12.3 & 27.7 & 10.8 & 24.2 & 0.99 \\
\hline Venezuela & 25.2 & 42.1 & 24.8 & 32.0 & 0.77 \\
\hline Average & 21.9 & 39.5 & 24.4 & 39.8 & 0.91 \\
\hline
\end{tabular}

Source: Based on Gelb (1989)

Note: The marginal propensity to consume out of revenues is defined as the ratio of the change in total expenditures to the change in total revenues. "NA" means not applicable. 
TABLE A.1: Business Cycle Properties for Individual Countries

\begin{tabular}{|c|c|c|c|c|c|c|}
\hline \multirow[b]{2}{*}{ Country } & \multicolumn{2}{|c|}{ Standard deviations } & \multicolumn{4}{|c|}{ Correlations with output (Y) } \\
\hline & $\mathbf{Y}$ & PC & PC & GC & $\mathbf{R}$ & $\mathrm{Pi}$ \\
\hline \multicolumn{7}{|l|}{ G-7 } \\
\hline Canada & 2.34 & 2.63 & 0.91 & 0.00 & 0.47 & 0.12 \\
\hline France & 1.55 & 1.19 & 0.85 & -0.28 & 0.41 & 0.24 \\
\hline Italy & 1.90 & 1.81 & 0.95 & 0.23 & 0.06 & 0.31 \\
\hline Japan & 1.74 & 1.96 & 0.81 & 0.18 & 0.21 & 0.46 \\
\hline United Kingdom & 2.69 & 3.27 & 0.87 & -0.15 & 0.07 & 0.25 \\
\hline United States & 2.10 & 2.70 & 0.85 & -0.07 & 0.66 & 0.13 \\
\hline Average & 2.05 & 2.26 & 0.87 & -0.02 & 0.31 & 0.25 \\
\hline \multicolumn{7}{|l|}{ Other OECD } \\
\hline Australia & 1.74 & 1.28 & 0.50 & -0.03 & 0.32 & 0.41 \\
\hline Austria & 1.62 & 1.36 & 0.84 & 0.17 & 0.61 & 0.48 \\
\hline Belgium & 1.84 & 2.31 & 0.84 & 0.27 & 0.56 & 0.37 \\
\hline Denmark & 1.84 & 3.20 & 0.79 & -0.23 & 0.84 & -0.15 \\
\hline Greece & 2.21 & 5.64 & 0.59 & -0.04 & 0.25 & 0.01 \\
\hline Iceland & 2.89 & 4.41 & 0.78 & 0.72 & 0.62 & -0.16 \\
\hline Ireland & 2.04 & 4.31 & 0.75 & 0.36 & -0.16 & 0.37 \\
\hline Netherlands & 1.74 & 2.64 & 0.82 & 0.60 & 0.48 & 0.29 \\
\hline New Zealand & 3.10 & 2.97 & 0.80 & -0.08 & 0.53 & 0.22 \\
\hline Norway & 1.75 & 2.47 & 0.69 & -0.06 & 0.05 & -0.09 \\
\hline Portugal & 3.09 & 4.77 & 0.47 & 0.67 & -0.22 & 0.04 \\
\hline Spain & 2.95 & 3.47 & 0.96 & 0.42 & 0.69 & 0.46 \\
\hline Sweden & 1.94 & 2.62 & 0.74 & 0.12 & 0.58 & 0.28 \\
\hline Switzerland & 2.54 & 1.92 & 0.91 & 0.57 & 0.31 & 0.61 \\
\hline Average & 2.24 & 3.10 & 0.75 & 0.25 & 0.39 & 0.22 \\
\hline \multicolumn{7}{|l|}{ Latin America } \\
\hline Argentina & 4.20 & 5.70 & 0.54 & 0.29 & 0.33 & -0.69 \\
\hline Bolivia & 3.90 & 5.50 & 0.51 & 0.44 & 0.40 & -0.41 \\
\hline Brazil & 3.95 & 5.18 & 0.16 & 0.18 & 0.22 & -0.17 \\
\hline Chile & 6.74 & 9.10 & 0.88 & 0.59 & 0.68 & -0.50 \\
\hline Colombia & 1.86 & 2.20 & 0.69 & 0.31 & 0.46 & 0.20 \\
\hline Costa Rica & 3.96 & 7.67 & 0.86 & 0.80 & 0.42 & -0.36 \\
\hline Dominican Republic & 2.70 & 5.10 & 0.26 & 0.10 & 0.50 & -0.12 \\
\hline El Salvador & 5.96 & 6.14 & 0.89 & 0.62 & 0.67 & 0.17 \\
\hline Guatemala & 3.64 & 2.54 & 0.90 & 0.41 & 0.36 & -0.06 \\
\hline Guyana & 6.06 & 32.63 & 0.46 & 0.63 & 0.57 & -0.06 \\
\hline Honduras & 3.63 & 2.69 & 0.70 & 0.37 & 0.78 & 0.04 \\
\hline Mexico & 3.66 & 6.28 & 0.93 & 0.77 & 0.61 & -0.35 \\
\hline Panama & 5.57 & 6.05 & 0.27 & 0.67 & 0.77 & 0.20 \\
\hline Paraguay & 5.06 & 3.59 & 0.60 & 0.66 & 0.48 & -0.23 \\
\hline Peru & 6.50 & 11.90 & 0.84 & 0.71 & 0.50 & -0.45 \\
\hline Uruguay & 5.10 & 7.78 & 0.90 & 0.53 & 0.51 & -0.40 \\
\hline Venezuela & 4.64 & 5.93 & 0.46 & 0.85 & 0.05 & 0.05 \\
\hline Average & 4.54 & 7.41 & 0.64 & 0.53 & 0.49 & -0.19 \\
\hline \multicolumn{7}{|l|}{ Africa } \\
\hline Burundi & 3.94 & 7.50 & 0.29 & 0.21 & 0.30 & -0.43 \\
\hline Botswana & 6.74 & 12.90 & 0.37 & 0.72 & 0.69 & 0.14 \\
\hline Ethiopia & 3.68 & 8.43 & 0.44 & 0.63 & 0.70 & -0.45 \\
\hline Ghana & 5.07 & 10.50 & 0.73 & 0.54 & 0.13 & 0.00 \\
\hline Kenya & 3.20 & 7.38 & 0.56 & 0.72 & 0.84 & -0.29 \\
\hline Madagascar & 3.20 & 6.52 & 0.40 & 0.59 & NA & -0.07 \\
\hline Mauritius & 4.88 & 9.38 & 0.64 & 0.80 & 0.74 & 0.02 \\
\hline Morocco & 2.97 & 2.53 & 0.20 & 0.58 & 0.44 & 0.21 \\
\hline Nigeria & 5.94 & 12.23 & 0.40 & 0.43 & 0.56 & -0.17 \\
\hline South Africa & 2.06 & 3.26 & 0.73 & 0.26 & 0.53 & 0.17 \\
\hline Tanzania & 2.35 & 12.47 & 0.56 & 0.46 & 0.58 & -0.23 \\
\hline Average & 4.00 & 8.46 & 0.48 & 0.54 & 0.55 & -0.10 \\
\hline \multicolumn{7}{|l|}{ Other Developing } \\
\hline Indonesia & 7.77 & 3.84 & 0.18 & 0.62 & 0.06 & 0.17 \\
\hline Israel & 9.30 & 14.98 & 0.89 & 0.81 & 0.81 & -0.65 \\
\hline Jordan & 5.65 & 11.00 & 0.71 & 0.56 & NA & -0.25 \\
\hline Korea & 2.22 & 6.56 & 0.62 & 0.60 & 0.75 & 0.22 \\
\hline Malaysia & 3.73 & 4.19 & 0.77 & 0.54 & 0.64 & 0.15 \\
\hline Singapore & 3.59 & 6.61 & 0.87 & 0.58 & 0.77 & 0.46 \\
\hline Siryan Arab Republic & 3.60 & 4.36 & 0.62 & 0.03 & 0.42 & 0.56 \\
\hline Thailand & 3.84 & 3.76 & 0.87 & 0.45 & 0.88 & 0.18 \\
\hline Average & 4.96 & 6.91 & 0.69 & 0.52 & 0.62 & 0.10 \\
\hline
\end{tabular}

NOTE: Statistics are based on Hodrick-Prescott filtered data. The sample period is 1970-1994.

Variables are: $Y$, real output; PC, real private consumption; GC, real government consumption; R, real total revenue,

$\mathrm{Pi}$, inflation tax as defined in the text. Data are annual from the IFS and GFS of the IMF, except for Argentina,

Bolivia, Brazil, Dominican Republic, and Peru which are from the IADB's internal database. 
Figure 1: Volatility and Procyclicality Giovernment Lonsumption

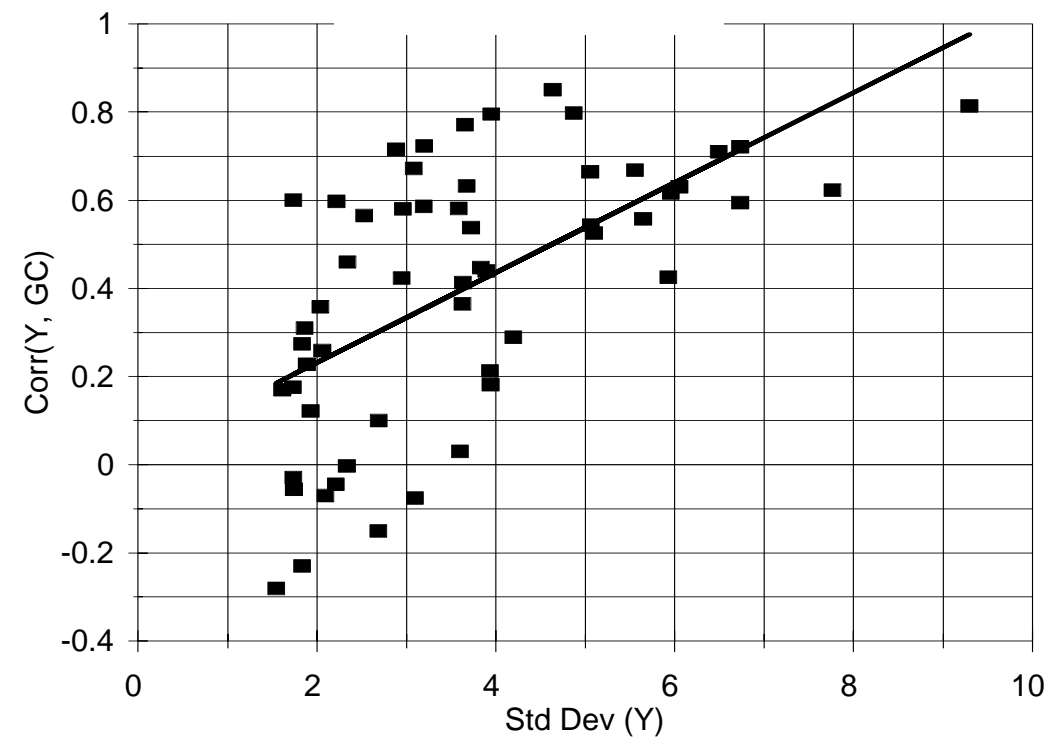

The regression line is given by $\mathrm{y}=0.03+0.10 \mathrm{x} ; \mathrm{t}$-statistic of coefficient $=5.48 ; \quad \mathrm{R} 2=0.36$

Figure 2: Volatility and Procyclicality Inflation Tax

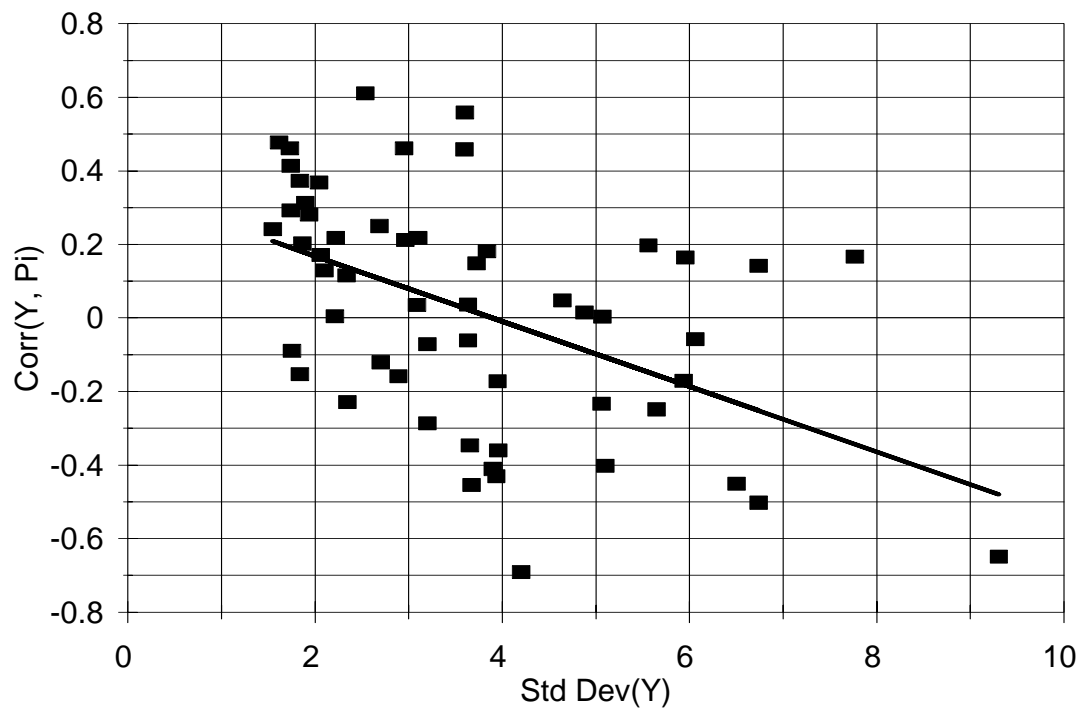

The regression line is given by $y=3.71-2.73 x ; t$-statistic of coefficient $=-4.15 ; R 2=0.24$ 